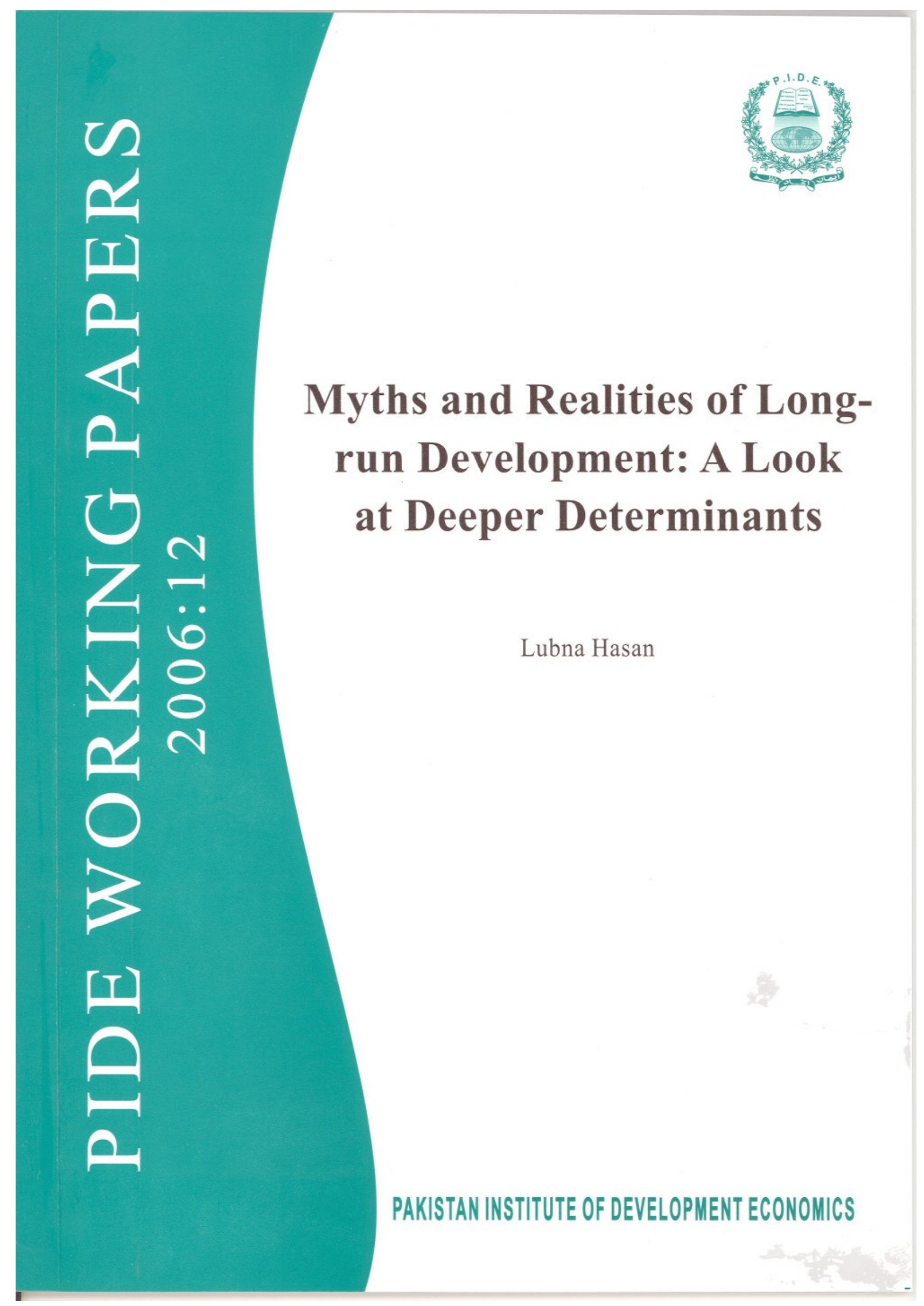




\section{Myths and Realities of Long-run Development: A Look at Deeper Determinants}

\section{Lubna Hasan}

Pakistan Institute of Development Economics, Islamabad

\section{PAKISTAN INSTITUTE OF DEVELOPMENT ECONOMICS} ISLAMABAD 
All rights reserved. No part of this publication may be reproduced, stored in a retrieval system or transmitted in any form or by any means-electronic, mechanical, photocopying, recording or otherwise-without prior permission of the author(s) and or the Pakistan Institute of Development Economics, P. O. Box 1091, Islamabad 44000.

\section{(C) Pakistan Institute of Development}

Economics, 2006.

Pakistan Institute of Development Economics

Quaid-i-Azam University Campus

Islamabad 45320, Pakistan

E-mail: publications@pide.org.pk

Website: http://www.pide.org.pk

Fax: $\quad+92-51-9210886$

Designed, composed, and finished at the Publications Division, PIDE. 


\section{CONTENTS}

$$
\text { Page }
$$

Abstract

1. Introduction

$\mathbf{v}$

2. Geography as Destiny 3

2.1. The Classics 3

2.1.1. Climate Conditions 3

2.1.2. Water as Power 5

2.2. The Contemporaries 6

2.2.1. Wealth and Poverty of Nations 6

2.2.2. The Resource Curse 6

2.2.3. 'Geography Determines' 7

2.3. Geography and Long-run Development 8

3. Institutions-The Fundamental Determinant 13

3.1. Defining Institutions 13

3.2. A Theory of Institutions 14

3.3. Institutional Account of Long-run Development 18

3.4. Empirical Evidence 21

4. The Root Cause: Institutions or Geography? 23

5. Conclusion and Policy Implications 30

References $\quad 31$ 


\section{List of Tables}

Table 1. Independent Origins of Sedentary Agriculture

Table 2. Distribution of Species Suitable for Domestication

\section{List of Figures}

Figure 1. Biogeography and Long-run Economic Development 10

Figure 2. GDP Per Capita $1995 \quad 24$

Figure 3. Average Protection against Risk of Expropriation 1985-95 and Log GDP Per Capita 1995

Figure 4. Urbanisation in 1500 and Log GDP Per Capita in 1995, among Former European Colonies

Figure 5. Urbanisation in 1500 and Average Protection against Risk of Expropriation 1985-95 


\begin{abstract}
It has long been realised that factor accumulation and technological development are only proximate causes of economic development, and focus has now shifted to investigating the 'deeper determinants' of economic growth. Two such forces are highlighted in literature: institutions and geography. However, it remains controversial as to which of these two is the more important. The "Institutions school" assigns primal importance to institutions, whereas the "Geography school" considers geographical factors as the primary determinant of economic performance of countries. This paper reviews the debate surrounding these "deeper determinants" of economic performance. It reviews the work of these two schools of thought and their interpretation of the long-run development. The paper then examines the evidence provided by the respective schools in favour of their hypotheses. It concludes in favour of the Institutions hypothesis as the Geography school does not provide a consistent story of long-run development.
\end{abstract}

JEL classification: O10, O43, N00, P51, R11

Keywords: Institutions, Geography, Long-run Development, Deeper Determinants of Growth 

Commerce and manufactures can seldom flourish long in any state which does not enjoy a regular administration of justice, in which the people do not feel themselves secure in the possession of their property, in which the faith of contract is not supported by law...

Adam Smith, Wealth of Nations (V, iii) (1776)

As by means of water-carriage a more extensive market is opened to every sort of industry than what land-carriage alone can afford it, so it is upon sea-coast, and along the banks of navigable rivers, that industry of every kind naturally begins to subdivide and improve itself...

Adam Smith, Wealth of Nations (I, iii) (1776)

\section{INTRODUCTION}

The world income is very unevenly distributed across countries. While the average annual income of one billion people living in high income economies is about $\$ 27000$ that of 2.5 billion people living in low income economies is a mere $\$ 430$ [World Bank (2004)]. To understand the gravity of the situation one just has to look at the per capita income of the world's richest country (Luxembourg \$56000) vis-à-vis that of poorest (Burundi \$90). Madison (1995) estimates that Africa was able to achieve levels of income in 1992 what Europe had achieved more than hundred and seventy years ago. ${ }^{2}$

What explains these phenomenal differences in economic performance? Until recently, economists had conveniently attributed it to the process of capital accumulation and technological development, in line with the predictions of neoclassical growth theory. ${ }^{3}$ Indeed, it was the dominant paradigm in the post world war II era when many newly independent countries were aspiring to join the league of developed countries. Massive injection of capital (both in the form of foreign aid and loan) was sought to free these lagging countries from resource constraint and speed up the process of capital accumulation, and hence foster

Acknowledgements: The author wishes to thank Dr Nadeem Ul Haque and Dr Musleh-ud Din for their valuable comments on an earlier draft of this paper. Any remaining errors and omissions are the author's sole responsibility.

${ }^{1}$ World Development Indicators (2005).

${ }^{2}$ In 1992, the average per capita income in Africa was estimated to be $\$ 1284$ (international \$), which is comparable to per capita income in Europe (1292 international dollars) in 1820.

${ }^{3}$ Along with its endogenous growth variant. The endogenous growth variant of neoclassical theory [Romer (1986) and Lucas (1988)] brings in the important role of innovation. 
growth. We all know by now that growth did not happen for a large number of countries.

Moreover, the theory was unable to provide explanation for some basic question as to why some countries accumulate more capital (and hence grow faster then others), while some fail to utilise available capital effectively. North and Thomas (1973) write, "if all that is required for economic growth is investment and innovation, why have some societies missed this desirable outcome?" They further write, "the factors we have listed (innovation, economies of scale, education, capital accumulation etc.) are not causes of growth; they are growth". ${ }^{4}$

So, now capital accumulation and productivity growth are considered as "proximate" causes only, and the focus has shifted to investigating "deeper determinants" of growth. ${ }^{5}$ What are these "deeper determinants"? Literature highlights two such candidates: one is geography and the other is institutions of the society. Though, there is consensus about the determinants, there is not much agreement about which one of these is more important. The "institutions school" argues for institutions as the fundamental cause, while the "geography school" considers geography as the primary determinant.

Adam Smith (1774), in writing about causes of wealth of nations, had stressed both. In fact, his two quotes at the beginning of this paper have become the most cited quotes. ${ }^{6}$ The first one points to the importance of organising principles of a society in achieving prosperity (through commerce and manufactures) and the second quote identifies its geographical correlates, i.e., where we can expect this activity to be located.

Consequently, a debate has ensued which remains inconclusive till today. Proponents of geography hypothesis claim that "geography determines" the growth prospects of a country, where as advocates of institutions hypothesis argue that "institutions rule". "While the two schools fight it out among themselves, we will try to give a comprehensive review of this debate.

The structure of paper is as follows. In the next two sections we will review the two schools of thought; their theoretical foundations, linkages with growth, and empirical evidence provided in support of their arguments. Section two reviews the geography school and the third section discusses the institutions school. The fourth section is devoted to the debate and the final section concludes.

\section{GEOGRAPHY AS DESTINY}

\footnotetext{
${ }^{4}$ According to them growth will not happen if existing economic organisation is not efficient.

${ }^{5}$ See Rodrik, et al. (2002) and Easterly and Levine (2003). Also see, Bloch and Tang (2004), Przeworski (2004), and Woods (2004) for review of some of the issues.

${ }^{6}$ These quotes have been used extensively by respective schools.

${ }^{7}$ Phrases like "geography determines" and "institutions rule" have become very popular in this debate.
} 
All the inland parts of Africa, and all that part of Asia which lies any considerable way north of the Euxine and Caspian seas, the ancient Scythia, the modern Tartary and Siberia, seem in all ages of the world to have been in the same barbarous and uncivilised state in which we find them at present.

The nations that, according to the best authenticated history, appear to have been first civilised, were those that dwelt round the coast of Mediterranean sea.

Adam Smith, Wealth of Nations (I, iii) (1776)

The geography school of thought has a long pedigree and dates as long back as Aristotle, ${ }^{8}$ but it is Montesquieu (1750) who is credited for presenting the first systematic theory linking geography with development of human society in his classical treatise The Spirit of Laws [Olsson (2003b)]. The focus of early writers of this school of thought was primarily on climate and its impact on human effort. Prominent among those were Huntington (1915) and GilFillan (1920). This strand of thought reached its zenith in the early decades of the twentieth century when it had considerable influence on the scientific community and civil society, especially in the developed parts of the world. Later, however, it fell into disrepute as "modern sensibilities" refused to accept its racial undertones. " Landes (1998) writes that geography had lost ground when, after World War II, Harvard University abolished its geography department, and many other universities followed suit. Of late, however, geography is enjoying a kind of renaissance, and a huge effort has been launched by contemporary writers on geography [Diamond (1997), Landes (1998), and Sachs, et al. (various publications)] to place it back into its lost position. This relaunch effort was based on the realisation that the early writers went "too far" [Landes (1998), p. 3]. Owing to its discontinuity, we divide the geography thought into the "classics", which includes the work of the early writers (e.g. Montesquieu, Huntington and GilFillan), ${ }^{10}$ and the "contemporaries".

\subsection{The Classics}

\subsubsection{Climate Conditions}

Montesquieu asserted that climate has a direst bearing on the temperaments and customs of a country's inhabitants. ${ }^{11}$ People of colder climates are vigorous, courageous, phlegmatic, disciplined, and more

${ }^{8}$ Aristotle is known for introducing the concept of "Meteorolgica", i.e. zone of habitable world (latitudinally oriented). Based on his observations, he conjectured that the most hospitable zones were the mid-latitude regions.

${ }^{9}$ Primarily, this school attributed the superior culture of the Western Europe (and its off shoots) to its colder climate.

${ }^{10}$ This list is by no means exhaustive; it rather represents the most influential works as noted by the research community [see Olsson (2003b) for this point].

${ }^{11} \mathrm{http}: / /$ plato.stanford.edu/entries/montesquieu. 
determined than people of hotter climates. ${ }^{12}$ People of hotter climates are more fearful and susceptible to temptations, less resolute and less capable of decisive action. The quality of soil was also important as it influenced the form the government might take. He theorised that fertile countries were more prone to be ruled by monarchies, whereas republics were more common in barren areas. ${ }^{13}$ Thus, he explains why Asia is more prone to despotism: first, it lacks temperate zones; second, Asia has much larger plains than Europe, hence, rendering it vulnerable so "the warlike, brave, and active people touch immediately upon those who are indolent, effeminate, and timorous; the one must, therefore, conquer, and the other be conquered" (Montesquieu, SL 17.3).

"No nation has risen to highest grade of civilisation except in regions where climate stimulus is great. This statement sums up our entire hypothesis". [Huntington (1915)].

Huntington (1915) is another major work on these lines. In "Civilisation and Climate" he sought to understand the reasons for the progress of human civilisations. His work, more scientific than that of Montesquieu in the sense that he based his assertions on results of field experiments, ${ }^{14}$ also linked climate with human activity. His main assertion was that mental and physical vigor were related to outside temperature. The ideal working conditions, according to him, are those in which temperature ranged between 38 degree Fahrenheit (mean winter temperatures) and 65 degrees (mean summer temperatures), found in temperate zones of the world. ${ }^{15}$ The right combination of temperature and humidity lends energy to people, which then enables them to be more honest, self-controlled, and willing to take initiatives. The tropical climate, on the other hand, weakens character through inducing a proneness to indulgence, inertia, and weakness of will [Whitebeck (1916)].

"The leadership in world civilisation is inseparably linked with climate". [GilFillan (1920), The Coldward Course of Progress].

\footnotetext{
${ }^{12} \mathrm{He}$ reasons that blood rushes faster through the veins in colder climates, making heart stronger, which meant that people of northern hemisphere had more vigor while those of southern hemisphere were lazy.

${ }^{13} \mathrm{He}$ gives three reasons for this assertion. First, fertile countries are more prone to invasions, (more desirable and easier to conquer as they "are always of a level surface" (SL 18.2)); second, people of fertile countries value their government for security and not liberty, and monarchies are better able to respond to external threats; third, inhabitants of barren countries are more "industrious, sober, inured to hardship, courageous, and fit for war" (SL 18.4), and hence better able to defend themselves. The inhabitants of fertile countries favour "ease, effeminacy, and a certain fondness for preservation of life" (SL 18.4).

${ }^{14}$ Huntington assembled data on the impact of weather changes on daily "nervous activity", productivity, "feelings and energy" [Stehr and Storch (1998)].

${ }^{15}$ Results of field experiments indicated that an average temperature of 65 degree Fahrenheit was optimum for physical work, and average temperature of 38 degree Fahrenheit maximised mental activity [Whitebeck (1916)].
} 
Above are the opening lines of the famous GilFillan's 1920 article. His explanation of the "Coldward Course of Progress" away from early centre of civilisations in Sumer and Egypt in the third millennium B.C (average temperature $\left.74^{\circ} \mathrm{F}\right)$, via Rome $\left(60^{\circ} \mathrm{F}\right)$ to Berlin $\left(48^{\circ} \mathrm{F}\right)$ in early twentieth century is primarily based on climate. He reasons that early civilisations appeared in hot climates because agriculture is easy to appear in warm regions, but later, as technology assumed a more important role, leadership moved northwards where conditions for mental ability were better. ${ }^{16}$ His argument was that "warmth was necessary for a nascent civilisation" as agriculture was most productive there, and an abundant food supply released hands for other occupations. However, with developments in agriculture technology (use of animals, tools) the importance of warmth diminished and its harmful effect on health and "mind" became prominent. Moreover, with the passage of time, civilisations have become less dependent on agriculture and more dependent on "handicrafts, manufactures, and clerical and other brain occupations" requiring mental vigor, "and so, with a civilisation depending on mental effort, the northern nations have gone ahead" [GilFillan (1920:398)].

\subsubsection{Water as Power}

In an interesting line of work linking geography with development, Karl Wittfogel (1957) develops a thesis that "Hydraulic Civilisations" (i.e. civilisations dependent on large scale irrigation networks) are more prone to be under some kind of despotic rule. This thesis is more popularly known as Oriental Despotism. He reasons that large scale irrigation networks implied specialisation and division of labour (for digging, dredging, tool making, etc.), an organisational hierarchy for coordinating and directing the activities of mass labour, and government control over distribution of water (to ensure proper distribution). This led to the development of impersonal governments (as against a tribal form of government) with control and monopolisation of political power, taking the shape of absolutist states. ${ }^{17}$ It also meant that agriculture production took place at large scale due to economies of scale. This resulted in highly stratified societies where ruling élite controlled mass of workers.

Criticism abound, these classical theories now constitute a disbanded line of research. ${ }^{18}$ Though, they continue to influence contemporary ideas in this area even today [Stehr and Storch (1998)].

${ }^{16}$ GilFillan writes that "fiery and volatile temperament of southern peoples renders them incapable of responsibilities and toils by which phlegmatic northern races have made great their states" [GilFillan (1920:396)].

${ }^{17}$ Wittfogel includes Egypt, Mesopotamia, India, China, and pre-Colombian Mexico and Peru in this list. http://www.riseofthewest.net/thinkers/wittfogel05.htm (adapted from on-line Encyclopedia Britannica's articles).

${ }^{18} \mathrm{Climate}$ theories were discredited for their racial undertones and lack of supportive evidence. Wittfogel's theis of Hydraulic Civilisations fits well ancient Chinese empire but is less befitting for Indian case which was unified only under the British rule. Moreover, Europe, despite its fragmented nature, was united under Roman empire for many centuries. 


\subsection{The Contemporaries}

\subsubsection{Wealth and Poverty of Nations}

Landes (1998) is one of the recent attempts to explain The Wealth and Poverty of the Nations cast in terms of geography. He attributes differences in relative prosperity of countries to differences in geographic endowments i.e. climate, disease and water. He writes that hot climate of the tropics not only implied adaptation of work habits to keep people inactive during midday (like siesta) ${ }^{19}$ but also had negative implications for the disease environment as year round heat meant proliferation of pest hostile to men. Tropical areas were also hindered in their development by an irregular supply of water. Rainfall, though enough on average, is irregular and unpredictable and downpours are extremely harsh, so "cultivation does not compete easily with jungle" [Landes (1998: 13)]. Storage of water for irrigation purposes is difficult on account of very high rates of evaporation.

In contrast to these so-called "Hydraulic Civilisations", Europe had (and still has) access to a heavy and reliable rain water, which meant that individual farmers were not reliant on a ruling elite managing the irrigation network. The fragmented nature of European continent implied intense competition among many small states with favourable consequences for trade, institutional development and individual freedom. European domination of the world was, eventually, helped by its unique topography [Landes (1998)].

Another feature of European topography that has received scholarly attention is its unique position in term of access to the Atlantic Ocean. Oceanic currents made it easy for Europeans to reach the Americas, which had abundant supplies of natural resources including precious metals. ${ }^{20}$ Dependency theorists assert that resources extracted from these colonies are partly responsible for the economic success of Europe and the underdevelopment of rest of the world.

\subsubsection{The Resource Curse}

This line of research links natural resource endowment (e.g. oil, minerals, diamonds) of a country with its growth potential. It draws its name from the empirical observation that resource rich countries (Latin America and some African countries) have experienced slower growth compared to resource poor countries (East Asian NICs). Many explanations are offered for this empirical regularity. One is the Dutch Disease Phenomenon. It typically refers to a situation where discovery of a primary natural resource appreciates the value of

\footnotetext{
${ }^{19} \mathrm{He}$ writes that "in British India, the saying had it, only mad dogs and Englishmen went out in the noonday sun. The natives knew better" [Landes (1998: 7)].

${ }^{20}$ See Acemoglu, Johnson and Robinson (2005b) for empirical verification of this point. Their theory, however, stresses that the effect of access to Atlantic on incomes works through institutions.
} 
currency for that country and diverts investment away from manufacturing and service sectors and hence lowers growth rate [De Silva (1994), Gylfason (2001a, 2001c), Gylfason, et al. (1999), Matsen and Torvik (2003), Mckinley (2005), Nakahodo and Jank (2006)]. Others have stressed the political economy consequences of rich resource base. They argue that natural resource abundance increases corruption and rent seeking activities and reduces incentives for productive activities [Auty (2004), Bulte, Damania, and Deacon (2005), Collier and Hoeffler (1998), Deacon and Mueller (2004), Eifert, Gelb, and Tallroth (2002), Gylfason and Zoega (2001), Gylfason (2001b), Olsson (2003a), Pritchett, Woolcock, Busby, and Isham (2004), Ross (2001,1999), Sachs and Warner (2001)].

\subsection{3. 'Geography Determines'}

Though a number of researchers have worked on re-invoking interest in geography as a possible explanatory factor behind different evolutionary pattern of regions overtime, but it is to the credit of Jeffery Sachs and his colleagues [Sachs (2003, 2001), Gallup, Sachs, and Mellinger (1999), Radelet and Sachs (1998), Gallup (1998)] that geography is finding its way back into theoretical and empirical studies of economic growth. In a series of papers these authors have tried to show that various measures of prosperity (per capita income, growth rates) are strongly correlated with geographical and ecological measures (climate zones, disease ecology, distance from coast etc.) [Sachs (2003)]. They assert that tropical regions are hindered in their development on account of low agriculture productivity, high disease burden, and high transport cost. ${ }^{21}$ Sachs (2001) proposes five hypotheses regarding tropical underdevelopment. He summarises his assertions as: (1) technologies in critical areas of health, agriculture, construction, energy use, and other manufacturing processes are specific to ecological zones; (2) by the start of modern era temperate zone technologies were more productive than tropical zone technologies; (3) technological development is an increasing returns to scale activity; ${ }^{22}(4)$ social change processes (especially urbanisation and demographic transition) amplified this gap; (5) geopolitical factors (European imperialism, control of international financial institutions by rich nations of the world) widened this divide even further [Sachs (2001)].

Gallup (1998) shows that agriculture productivity is sensitive to ecological conditions (climate, water availability, and soil fertility). His empirical findings suggest that, compared to the temperate zones, agriculture productivity is $30-35$

\footnotetext{
${ }^{21} \mathrm{High}$ transport costs are due to (1) limited access to sea and ocean navigable rivers (a high percentage of population living in hinterlands, higher number of landlocked economies), and (2) greater distance from major economic centers of the world.

${ }^{22} \mathrm{He}$ considers this to be the main amplifier of gap between temperate zone and tropical zone economies.
} 
percent lower in the tropics. Gallup and Sachs (2001) document evidence of geography affecting the economic performance of countries through higher disease burden. They show that countries with intensive malaria had 33 percent lower incomes than countries without malaria. Radelet and Sachs (1998) estimate that landlocked country, where shipping cost are magnitude of a degree higher than similar coastal economy, experiences slower growth. ${ }^{23}$ Their argument will be taken up again in Section (4) where we discuss the debate.

\subsection{Geography and Long-run Development}

One of the most influential and controversial work, in recent times, on geography and economic development over the long run is that of Diamond (1997). The question that he seeks to address through his work Guns, Germs and Steel: The Fates of Human Societies ${ }^{24}$ is, "Why did Europe colonise America (and other parts of the world) and not the other way round?" $\mathrm{He}$ asserts that Europe had superior technology and political organisation compared to any other region around 1500 A.D.- the time when epoch of colonisation began to take place. He attributes this to different rates of development on different continents from 11,000 B.C. ${ }^{25}$ to A.D. 1500. Areas that made an early transition to settled agriculture were the ones that developed skills of writing, metallurgy (guns, swords etc.), and complex political organisation. So the time when European colonisers met the Native American people, and later Aboriginal Australians, they were armed with steel swords and guns while their opponents still had weapons made of stone and wood. Europeans colonisers also had the means to reach the Americaslarge ocean going ships, navigation skills, maps, sailing directions and accounts by earlier explorers etc. He also stresses the role played by infectious diseases (smallpox, measles), which were introduced by the Europeans, in the demise of Native Americans. He estimates that around 95 percent of the local population was killed by these diseases. These epidemic diseases, a phenomenon of dense human population in cities and towns, find their origin in similar epidemic diseases of dense population of domestic animals with which the people of old world came in contact with.

\footnotetext{
${ }^{23} \mathrm{~A} 10$ percent increase in distance from the sea is associated with 1.3 percent increase in shipping costs. An increase of 50 percent in shipping costs reduces growth rates by 0.3 percent per annum [Radelet and Sachs (1998)].

${ }^{24}$ Typically he asked why a few hundred Spaniards under CortŽs and Pizarro overthrew the Aztec and Inca Empires? Why Emperors Montezuma or Atahuallpa did not lead the Aztecs or Incas to conquer Europe?

${ }^{25}$ Diamond asserts that 11,000 B.C. is a suitable starting point from which to compare historical developments on the different continents, because this date corresponds to the end of the Pleistocene Era and last Ice age (start of the recent era in geological terms). This date also corresponds to the beginning of the village life in some parts of the world. Domestication of plants and animals started within a few thousand years of this date [Diamond (1997: 35)].
} 
Why these differences in the level of technology and in the immune systems? Diamond's thesis goes as follows: Eurasia $^{26}$ (owing to its large size and Mediterranean climate) was naturally endowed with the highest number of animal and plant species that could be domesticated. Whereas most of the large mammal species of the North and South America had become extinct by the end of the last ice age 13,000 years ago, Europe still had a large number of animal ${ }^{27}$ and plant species (partly owing to its large land mass) that were suitable for domestication. Eurasia's east/west axis meant easier diffusion of these species across the whole region. ${ }^{28}$ In contrast, the north/south axis of the America made this diffusion difficult. ${ }^{29}$ Similarly for Africa, which should have enjoyed enormous head start over Europe because humans have been evolving there millions of years longer than in Europe, limited availability of plants and animals that were suitable for domestication and north/south orientation had implications for later development (or lack of it). ${ }^{30}$

Domestication of plants and animals had far reaching consequences for the Eurasian region. Domestication of animals revolutionised land transport. It also revolutionised agriculture. Use of animals in agriculture meant that the farmer could till larger tracts of land then he could do so with his own effort alone. Domestication of plants meant more calories per acre compared to wild habitat where most species are inedible. Dense population settlements began to emerge. Food surpluses generated in agriculture led to increased specialisation of work force ${ }^{31}$ and emergence of "stratified and politically centralised societies" with ruling elites. These developments were accompanied by

\footnotetext{
${ }^{26}$ Includes Europe, parts of Asia, near East, and the Fertile Crescent.

${ }^{27}$ Native Americans, by contrast, inherited only limited species of domesticated animals (llama and alpaca).

${ }^{28}$ Animals and plants that were domesticated in one part of the continent could travel to other parts without encountering great variation in day length and climate. So "chicken and citrus fruits domesticated in Southeast Asia quickly spread westward to Europe; horses domesticated in the Ukraine quickly spread eastward to China; and the sheep, goats, cattle, wheat and barley of the fertile crescent quickly spread both west and east" [Diamond (1997), http://www.edge.org/ 3rd_culture/diamond/diamond_p1.html].

${ }^{29}$ Plants and animals domesticated in one part could not travel to other part without encountering changes in day length and climate. So, Turkey never traveled from Mexico to Andes, and llamas and alpacas from Andes to Mexico, and the Central America remained without pack animals. Diamond further writes that "it took thousands of years for the corn that evolved in Mexico's climate to become modified into a corn adapted to the short growing season and seasonally changing day length of North America" (Diamond ibid).

${ }^{30}$ All of Africa's domesticated animals (cattle, sheep, goats, and horses) traveled from Eurasian continent. Africa's big wild animals proved unsuitable for domestication (due to their social behaviour, breeding habits etc.). Food staples of ancient Egypt (wheat and barley), which require winter rains and variation in day length for their germination, could not spread southwards because Central Africa had summer rains and relatively constant day length. Agricultural development in Sub Saharan Africa had to await the domestication of native plant species i.e. sorghum and millet.

${ }^{31}$ Not everyone had to grow food for himself so some hands were free for other occupations.
} 
technological advancement as craftspeople (those who were not engaged in agriculture) devoted themselves to science of metallurgy, and writing etc. The end result was that Eurasia had advantage in guns (and germs), swords, oceangoing technology (Large ships, maps and other navigation tools) political organisation, and writing, all of which were products of large, dense, sedentary, stratified societies made possible by agriculture. This early advantage allowed Eurasia to colonise the Americas and Africa [Diamond (1997)].

Olsson and Hibbs (2000), in an interesting and innovative work, encapsulate the essence of Diamond's (1997) theory, and test it empirically. It is worth summing up Diamond's work in a few lines. He basically argued that the Eurasian continent-owing to its enormous size, its East-West orientation, and large Mediterranean climate zone-was naturally endowed with a rich biogeographic potential. This led to an early emergence of settled agriculture in this region. Food surpluses, generated by superior agriculture technology, made possible the development of a non-food producing class which then engaged in creation of knowledge and other innovative activities which resulted in the development of writing, military and transport technology that put Eurasia ahead of other continents. In short, their testable hypothesis is that the initial biogeographic conditions ${ }^{32}$ determined the timing of transition to sedentary agriculture. The resultant (accelerated) technological progress ${ }^{33}$ yielded regional development advantages that to some degree affect present day per capita incomes. The following figure describes the sequencing of their logic.

Fig. 1. Biogeography and Long-run Economic Development

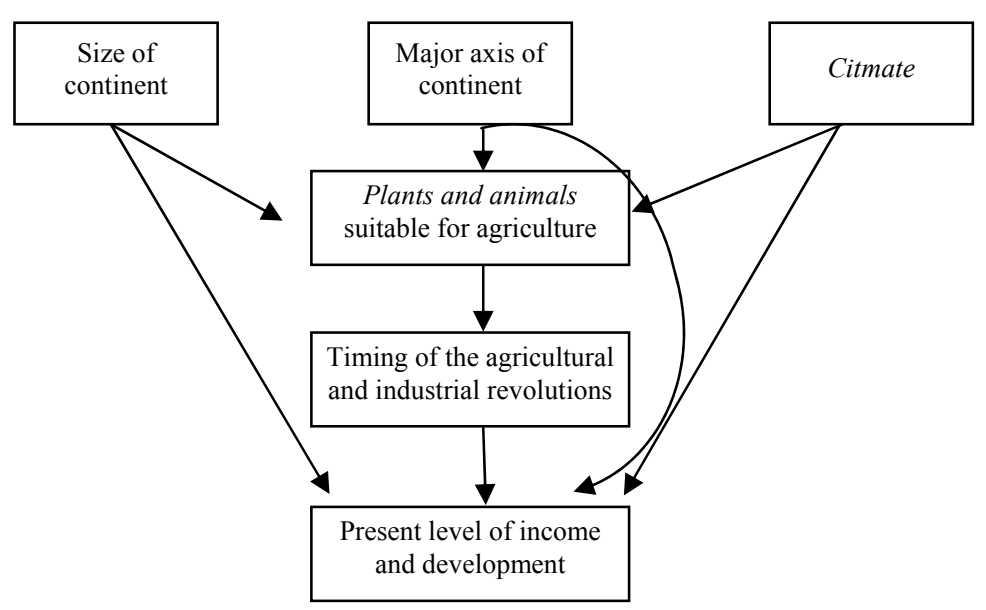

Source: Olsson and Hibbs (2000).

\footnotetext{
${ }^{32}$ i.e. biogeographical conditions 12,000 years ago, before the onset of settled agriculture.

${ }^{33}$ See Diamond (1997) for this argument.
} 
Agriculture first appeared in the Fertile Crescent around 8500 B.C. ${ }^{34}$ The first signs of domesticated barley and einkorn wheat appeared in the Jordan Valley along with the domestication of goats, sheep, pigs and later cattle. About 4500 years later, the first civilisation emerged in the river valleys of Tigris and Euphrates. ${ }^{35}$ China followed suit after about a thousand years and Central Mexico 5000 years later. Agriculture did not spread south towards Andes where agriculture was based on potato and manioc.

Areas where agriculture first appeared had many commonalities. In all regions seed plants were brought under domestication; their wild ancestors were important food sources of hunters and gatherers. These areas had rich varieties of wild plants and animals and reliable sources of water (rivers, lakes), and these people lived in relatively dense permanent communities [Smith (1998), cited in Hibbs and Olsson (2000:7)]. Moreover, the first strand of domesticated wheat appeared near garbage heaps, forest paths, and cooking places where these seeds might have been left unintentionally [Diamond (1997), cited in Hibbs and Olsson (2000:7)]. They also had elementary-level technology for settled agriculture, e.g., flint blades. Table 1 below depicts the dates of transition to settled agriculture.

Table 1

Independent Origins of Sedentary Agriculture

\begin{tabular}{lccc}
\hline Area & Date & Domesticated Plants & Domesticated Animals \\
\hline Near East & 8500 B.C. & wheat, barley pea & goats, sheep \\
China & 7500 B.C. & Rice, millet & pig \\
Central Mexico & 3500 B.C. & Corn, beans & turkey \\
South Central Andes & 3500 B.C. & Potato, manioc & llama, guinea pig \\
Eastern United States & 2500 B.C. & sunflower & None \\
Sub-Saharan Africa & 4000 B.C. & sorghum & None \\
\hline Adapted from Olson and Hibbs $(2000)$. & &
\end{tabular}

The evidence suggests that agriculture first appeared in regions that had relatively rich supplies of plants and animals suitable for domestication. Out of 56 heavy seeded wild grasses that are suitable candidates for domestication, as many as 33 are found in the Western part of Eurasia, i.e., the Mediterranean zone of Near East (see the table below). Further, out of

\footnotetext{
${ }^{34}$ These dates are calibrated radiocarbon dates and refer to the first attested date of domestication of an animal or plant.

${ }^{35}$ The civilisation had developed writing, science, religion, cities, and states.
} 
148 species of animals ${ }^{36}$ that are suitable for domestication, and of which only 14 have ever been domesticated, 9 are found in the Near East [Hibbs and Olsson (2000: 9)]. It is clear from the Table (2) below that Eurasia had a rich biogeographic potential for agricultural development as compared to other regions of the world.

Table 2

Distribution of Species Suitable for Domestication

\begin{tabular}{lcc}
\hline Area & Number of Plants & Number of Animals \\
\hline Near East, Europe, North Africa & 33 & 9 \\
East Asia & 6 & 7 \\
Southeast Asia & 6 & 2 \\
Sub-Saharan Africa & 4 & 0 \\
North America & 4 & 0 \\
Central America & 5 & 0 \\
South America & 2 & 1 \\
Australia & 2 & 0 \\
Pacific Island and Iceland & 0 & 0 \\
\hline Adapted from Olsson and Hibbs (2000). & &
\end{tabular}

While Diamond (1997) did not make an effort to link biogeographic potential with the present level of well-being, Hibbs and Olsson (2000) fills up this gap. They develop a framework that provides a link between initial biogeographic endowment and present day incomes, and explains economic development over three major stages of history; the hunter-gatherer stage, the agriculture stage, and the industrial stage, based on following 'stylised facts' (1) agriculture first emerged in areas with rich biogeographic potential, (2) there were no 'inherent differences in ability' of huntergatherers to exploit their natural environment, (3) agriculture development lead to emergence of a class of people ${ }^{37}$ who did not have to get involved in food production and lived on food surpluses generated by the agriculture sector, (4) the emergence of non-food sector set off a process of endogenous knowledge creation and population expansion, (5) living standards did not increase much before the industrial revolution. Results of the empirical exercise validate their hypothesis. In addition, it provides evidence that initial biogeographic potential has direct effect on incomes even today.

We conclude our discussion of the geography school here and now turn to the institutions school.

${ }^{36}$ Big herbivorous mammals.

${ }^{37} \mathrm{Chiefs}$, craftsmen, and bureaucrats. 


\section{INSTITUTIONS-THE FUNDAMENTAL DETERMINANT}

"[C]ommerce and manufactures gradually introduce order and good government, and with them, liberty and security of individuals... This, though it has been least observed, is by far the most important of all their effect."

Adam Smith, Wealth of Nations (book III, chapter iv)

"Individuals must be lured by incentives to undertake the socially desirable activities."

North, D. and R. P. Thomas, The Rise of The Western World (1973)

The idea that institutions matter for economic outcomes had long been realised in the writings of Adam Smith and John Stuart Mill, but it is North (1990) who is credited for outlining a theory of institutions and incorporating them in mainstream economics. ${ }^{38}$ The basic idea that this school of thought propagates is that "institutions matter" ${ }^{39}$ Markets, which are the hallmark of Western capitalist system and are responsible for the unprecedented expansion of economic activities, do not exist in vacuum. They are supported by a complex web of institutional infrastructure [Grief (2005)]. Even a simple exchange, e.g. purchase of oranges in public market, is "complex in terms of its fundamental characteristics...Underlying the transaction-making it possible-[i]s a complex structure of law and its enforcement" [North (1981), p. 35]. ${ }^{40}$

Before we discuss relevance of institutions for economic performance, we have to define what institutions are? What is their purpose?

\subsection{Defining Institutions}

Institutions are the rules societies live by. They are humanly devised constraints that shape and guide human interactions [North (1990:3)]. Rawls defines institutions as a "public system of rules that specify certain actions as permissible, other as forbidden, and provide for certain penalties and defenses when violations occur" [cited from Runge (1984, p. 807)].

North (1990) differentiates between formal and informal constraints. Formal constraints are the rules devised by human beings to facilitate exchange. ${ }^{41}$ Informal constraints are the norms, conventions, and code of ethics

${ }^{38}$ North's earlier work [North $\left.(1973,1981)\right]$ was also an effort to highlight importance of institutions, but the theory was finalised in his work, "Institutions, Institutional Change and Economic Performance" (1990). Also see Eggertsson (1990) for how economic behaviour is influenced by institutions.

${ }^{39}$ See Harriss, Hunter, and Lewis (1995), Nabli and Nugent (1989), Aron (2000), Jütting (2003), and Bennedsen, Malchow-Møller, and Vinten (2005) for review of the institutions school.

${ }^{40}$ Implying that the property rights of buyers and sellers are recognised and enforced by a system of law.

${ }^{41}$ These include political (and judicial) rules, economic rules and contracts. Among these, economic rules have received considerable attention in the current literature on institutions and growth. Basically, economic rules define property rights. Property right is the right to use, earn income from and alienate a resource [Barzel (1989)]. 
that societies evolve over time. ${ }^{42}$ In line with this approach, Greif (2005) deconstructs institutions into four components; between organic (informal) and designed (formal), and between private order and public order.

Rules are not always self-enforcing, and this brings in the important role of enforcement mechanism. In fact, North (1990) devotes considerable attention to this issue. Enforcement would not be a problem if parties to exchange have complete (and costless) information ${ }^{43}$ about each other and exchange is mutually beneficial for both of them. It becomes a problem when information is costly and incomplete, ${ }^{44}$ and benefits from shirking are substantial. When information is incomplete "the cooperative solution will break down unless institutions are created that provide sufficient information for individuals to police deviations" [North (1990: 57)].

Thus, an integral part of any institution is the enforcement mechanism; ways to ensure that rules are observed, and punishment is enacted when rules are violated. The costliness of ascertaining violations and the severity of punishment are considered to be an essential part of the functioning of institutions [North (1990)]. North argues that ultimately those institutions are required that can use threat of coercion to enforce agreements, and the state is the only authority that can exercise this threat of coercion. ${ }^{45}$ These rules and enforcement mechanisms are the essence of institutions.

\subsection{A Theory of Institutions}

The central problem in North's theory of institutions is the problem of cooperation-cooperation that allows individuals and societies to capture gains from trade.

The neoclassical theory of exchange envisions a frictionless economy where (1) markets are competitive, (2) property rights are perfectly defined and costlessly enforced, (3) information is perfect and parties to exchange have mental abilities to process this information, (4) governments are neutral, and (5) tastes are unchanging [North (1978: 964)]. In short, it assumes a situation where transaction $\operatorname{costs}^{46}$ are zero. The fundamental problem with this theory, according to North, is that it misconstrues the nature of human coordination and cooperation.

In real life situations cooperation cannot be taken for granted. One particular instance of cooperation failure that has received considerable attention in game

\footnotetext{
${ }^{42}$ These constraints are more pervasive then formal rules. This differentiation helps him explain why same formal rules when applied to different societies yield different results.

${ }^{43}$ i.e. the cost of measuring the multiple margins of performance.

${ }^{44}$ In real life situations information is incomplete and highly asymmetrical [see Akerlof (1970)].

${ }^{45}$ North (1981) writes that the state, as a third party, can reduce transaction cost by developing an impersonal body of law and its enforcements.

${ }^{46}$ Transaction costs are costs of defining, protecting and enforcing property rights [Barzel (1989)] and contracts.
} 
theoretic framework is that of 'prisoner's dilemma ${ }^{47}$ that was the mainstay of Hardin's 'Tragedy of the Commons' ${ }^{48}$ Although the theory has come under serious attack, and very few people believe in real life application of it, it did bring to the forefront the problem of 'opportunism, ${ }^{49}$ and 'shirking'. The theory points to the impossibility of rational, wealth maximising individuals to cooperate.

Later developments in game theory acknowledge the emergence of cooperative behaviour given game is repeated a number of times, each player has perfect knowledge about the past strategy of other players, and number of players is small. This framework fits well a situation of personal exchange in our daily life but fails to explain impersonal exchange, which, as North (1990) writes, is an antithesis of the condition for game theoretic cooperation. "As we move away from choices involving personal and repetitive actions to making choices involving impersonal and non-repetitive exchanges the uncertainty about outcomes increases." [North (1990: 22)].

This uncertainty comes from incomplete information about the behaviour of other individuals in the process of human interaction. Even if complete information was available, individuals have limited mental capacity to process, organise and utilise information-bounded rationality. ${ }^{50}$

${ }^{47}$ Prisoner's dilemma is visualised as a non-cooperative game in which communication among players is forbidden. Each player has complete information about the full structure of the game tree and the payoffs attached to outcomes. Each player has a dominant strategy, meaning that the player is always better off choosing that strategy. The game is built round two players. Two suspects are being interrogated for a crime they jointly committed. They know that if both remain silent they will receive a light prison sentence. If one stays silent while the other confesses the first will receive a long prison and the other will go free. If both confess they receive a medium prison. Each person chooses only once, meaning that if the first person stays silent and the other confesses the first one cannot change the outcome. This then creates the dilemma. Their joint interest is not to confess (i.e. cooperate so both get light prison). From the point of view of either one of them, staying silent while the other confesses gives the worst outcome (long prison). Confessing at least ensures that this outcome will be avoided. So the rational strategy for both of them is to confess, and this is their dominant strategy, and this results in a Pareto inferior outcome.

${ }^{48} \mathrm{Hardin}$ envisions a grazing ground which is "open to all". He then examines the situation from the point of view a "rational" herdsman. Each herdsman has a utility function, which he seeks to maximise; he derives positive utility from selling his animal and negative utility from overgrazing. Each herdsman is motivated to add more and more to his herd because he reaps the full, and direct, benefit from his animals but bears only a part of the cost resulting from overgrazing, so "each man is locked into a system that compels him to increase his herd without limit—in a world that is limited. Ruin is the destination towards which all men rush, each pursuing his own best interest in a society that believes in the freedom of the commons" [Hardin (1968: 1244)].

${ }^{49}$ Opportunism may loosely be defined "as the ability of one party to an exchange to benefit at the expense of the other party by violating the agreement in his or her post-contractual behaviour" [North (1981: 36)]. Main criticism against Hardin's tragedy of the commons is that it assumes no communication among individuals and no information about past behaviours which does not reflect real life situation facing any individual.

${ }^{50}$ This concept owes its origin to Simon $(1957,1955)$. While traditional economic theory assumes that a rational economic man has complete information and computational skills to analyse this information while making a decision, Simon (1955) holds that neither is true. In reality, information is not complete, and the individual has limited mental capacity to analyse available information. He terms this concept as 'bounded rationality'. 
This bounded rationality, combined with uncertainty in deciphering the environment, imply the need to develop regularised pattern of human interactions called institutions (ibid). As such, institutions perform a coordinating function in the society. Rules, by and large, eliminate conflicts of interest, and reduce the total amount of ambiguity for those concerned by defining what people can expect from fellow human beings. It becomes possible to order one's life with a set of priority regarded as legitimate [Colson (1974), c.f. North (1990), p. 38]. Individuals impose constraints upon themselves to give a structure to their life and to their relations with other human beings. Under conditions of limited information and bounded rationality, these constraints reduce the cost of human interaction as compared to a world without institutions [North (1990)].

The other important element of his theory is the transaction costs. The transaction costs specifically consist of the cost of measurement, and the cost of enforcement. The measurement costs are the cost of measuring the valuable attributes of what is being exchanged. Commodities, services and performance of individuals have many attributes and their level vary from one specimen to another. The measurement of these levels is too costly to be comprehensive or fully accurate. The information cost in ascertaining the level of attributes yields measurement costs. The enforcement costs are the cost of protecting rights and policing and enforcing agreements. These arise from incomplete information. Because we do not know the attributes of a good or service or all characteristics of the performance of an agent we have to devote costly resources to try to measure and monitor performance. North (1990) argues that "these measurement and enforcement costs are the sources of social, political and economic institutions" [North (1990: 27)].

Three main points emerge from his theory. First, outcomes are uncertain under impersonal exchange; second, information is not perfect and human beings have limited capacity to analyse that; third, the transaction costs are positive. Together these constitute the building blocks of his theory. Given these, institutions are needed for an exchange to take place and as such, they affect the performance of the economy by their effect on the cost of exchange. ${ }^{51}$ We will explain this point with the help one particular type of institution-the property institution, as North and Thomas (1973) write, "economic growth will occur if property rights make it worthwhile to undertake socially productive activity" [North and Thomas (1973: 8)].

\footnotetext{
${ }^{51}$ Runge (1984) argues that institutions "increase the value of a stream of benefits associated with economic activity by coordinating behaviour" [Runge (1984: 807)]. It is necessary to make one qualification to this statement. Institutions are not always growth enhancing. They have the potential to increase output from economic activity, i.e., if appropriate rules are devised and enforced. In most third world countries institutions are not efficient. They are not even meant to be efficient. Rather "they are created to serve the interests of those with the bargaining power to devise new rules" [North (1990: 16)].
} 
As again, we begin by defining property system (read institution) and property rights. Property system is a system of rules governing access to and control over resources. Property systems are central to an economic system as they solve problem of allocation of resources [Waldron (1988: 38)]. Property rights are relations among individuals that arise from the existence of scarce goods and pertain to their use. They specify the norms of behaviour with respect to economic goods that all persons must observe in their interaction with other people or bear the penalty cost of non-observance [Pejovich (1990)].

Since property rights determine the conditions of access to and control of these scarce resources, a set of particular property right has impact on the economic performance of the economy. ${ }^{52}$ Posner (1973) argues that the function of property rights is to create a structure of incentives to use resources efficiently. ${ }^{53}$ A "well-defined" structure of property rights would have four important features, i.e., rights are universal, exclusive, transferable and enforceable. ${ }^{54}$

Exclusivity implies exclusive ownership and a right to exclude nonowners. It creates a link between one's right to choose how to use the asset and bearing the consequences of that choice. Since the owner of the asset is the only person who will receive benefits from that decision, he will have an incentive to put his asset to the highest value use. Transferability provides incentive to move resources from less productive to more productive opportunities [Pejovich (1990:29)]. Enforceability means security from involuntary seizure or encroachment by others, what Honore (1961) calls a right to security against the expropriation of the asset. ${ }^{55}$

Together these four conditions determine an efficient structure of property rights. In case of an inefficient structure of property rights, i.e. when rights are either not well defined and or not enforced, the private rate of return from an economic activity will differ from the social rate of return. This discrepancy implies that a third party will receive some of the benefits or will incur some of the costs. If this difference is large enough, such that the private costs exceed the private benefits, individuals will not be willing to under take socially profitable activities. Economic activities will shrink as a result. "The transfer of property rights amongst individual owners through contracting in the

${ }^{52}$ This point is advocated by the so-called 'Property Rights School'. They stress that a welldefined structure of property rights induces efficiency in the use of resources. Demsetz (1967) is one of the pioneering work in this field. Other prominent supporters of this view include Posner (1973); Pejovich (1990); Tisdell (1993); Tietenberg $(1992,1994)$

${ }^{53}$ Cited from Reeve (1986), p. 23.

${ }^{54}$ The first three features are identified by Posner (1973) (cited from Reeve 1986) and the last feature is highlighted by Tietenberg (1992).

${ }^{55}$ Reeve (1986) discusses that interest in a resource is conceptually linked to the means available to protect it. A claim to a resource is taken to be good against and legally guaranteed against any rival claims. 
market place requires that the right be exclusive. Not only must the rights be measurable; they must also be enforceable" [North (1981: 36)].

\subsection{Institutional Account of Long-run Development}

History matters. It matters not just because we can learn from the past, but because the present and the future are connected to the past by the continuity of a society's institutions... The evolution of institutions that create an hospitable environment for cooperative solutions to complex exchange provides for economic growth.

Douglas North, Institutions, Institutional Change and Economic Performance (1990)

What explains unprecedented increases in the fortunes of the Western World over the last couple of centuries? Douglas North, in a long span of both collaborative and individual research [North $(1973,1981,1990)]$, explains the economic rise of the Western World in terms of the evolution of its institutions from inefficient to efficient ones. In discussing the contours of European society between 1100 and 1800, North and Thomas (1970) write that productivity increases during this time period can only be explained by a theory of institutional change [North and Thomas (1970: 4)]. Europe's recent economic successes are attributed to the industrial revolution. They argue that significant changes had occurred in the European society before this epoch that allowed it to take advantage of such an opportunity-break down of feudal culture that created space for establishing private property rights, and institutional innovations that solved problem of exchange and allowed market to expand were the starting points. From there onwards, it were individuals and organisations, in pursuit of profits, that capitalised on these early institutional innovations. Below is a brief account, as described in their work, of historical evolution of the European (mainly focusing upon English) society, basically from a common property based to exclusive ownership and personal village level exchange to an impersonal exchange.

Around the middle of twelfth century, Europe experienced considerable expansion of population and colonisation of new territories. This posed no problem as abundant arable land was available, so population spread out to north and west over Europe. Commerce thrived as different climates and resource base induced a variety of crops. Towns grew as population density increased. The era also saw the monetisation of services as lords chose to receive money payment in lieu of mandatory defensive services. Towns developed their own administrations and bodies of law to settle disputes. By the thirteenth century, however, the situation changed dramatically. Ever increasing population implied that relative factor intensities of agriculture production changed. Good quality land had become scare and labour was abundant. Food prices increased, real wages declined, and standard of living of peasants declined as a result. Despite all this, commerce continued to 
flourish in Italy, France, Germany and other parts of Europe [North and Thomas $(1970,1973)],{ }^{56}$ and the same era saw considerable expansion of trade.

The fourteenth century once again saw a reversal of relative product and factor values. The famine of 1315-17, and the black death ${ }^{57}$ of 1347-51 caused a decline in the population. Marginal lands went out of production. Some land was shifted to livestock production. Land rents declined for the landlords and real wages of labour increased. Bonds of manorialism became weak as land leases were lengthened, and the tenants began to acquire exclusive rights over land. So, by the time population began to rise again in the last half of fifteenth century, the structure of feudal society and lord-serf relations had changed. Agriculture prices increased once again and real wages declined. The sixteenth century saw the same trend of falling real wages and rising agriculture prices. What made this century different from the thirteenth century was substantial improvements in the transportation sector. Progress in ocean navigation technology resulted in discoveries and settlement of the New World, so Malthusian checks dampened. Structure of property rights evolved (from common property based to exclusive property) and England saw the first effort at "enclosures". The sixteenth century was also an era of commercial expansion. Interregional trade was possible because spread of population into new territories opened up areas with different resource endowments. Wine trade expanded because viticulture was possible in many new areas and fine wine was in demand. Wool trade, particularly of woolen cloth, also expanded. ${ }^{58}$ An additional factor contributing to expansion of trade was the influx of treasures from the New World, as it contributed to increased size of the market and provided impetus for trade. As a consequence, substantial institutional innovations took place described as "commercial revolution" [North and Thomas $(1970,1973)] .^{59}$

Commercial revolution is considered as the most important economic epoch after the Neolithic transformation. Greif, Milgrom, and Weingast (1994) write that the "European economic growth between the tenth and fourteenth centuries was facilitated by the commercial revolution of the Middle Ages" [Greif, Milgrom and Weingast (1994: 746)]. This commercial revolution was made possible by the development of institutions that took care of many contractual problems associated with long distance trade [Greif $(1989,1993,2003)]$. Long distance trade in medieval times was afflicted with many problems. One was the agency problem. Traders used to send their cargo to distant market through agents. One difficulty was to ensure that the agent did not deceive the principal. This problem was solved by the use of kinship ties (commenda). The second problem was the commitment

\footnotetext{
${ }^{56}$ Reasons of expansion of commerce will be discussed shortly.

${ }^{57}$ The Black Death refers to the plagues (both bubonic and pneumonic) that hit Europe during 1347-51.

${ }^{58}$ Presumably, expansion of population into the north of Europe increased the demand for woolen cloth.

${ }^{59}$ Some of these institutional innovations were the beginning of joint stock companies, sophisticated forms of insurance, development of international financial markets.
} 
problem i.e. of contract fulfillment and enforcement [North (1990)]. Long distance trade, owing to geographic separation of trading parties, is specified by the separation of quid and quo, ${ }^{60}$ which lends an extra element of risk to it. If goods are delivered before payment is made then seller is taking a risk because buyer can change his mind, and vice versa. The problem was compounded by the issues of jurisdiction. City states could enforce contracts within their territories but could not enforce agreements when the other contracting party was in distant city. "The separation of the quid and the quo created the possibility that one party, however well-intentioned ex ante, would find it to his advantage ex post to reopen the bargaining or simply welsh on the deal" [Dam (2006: 3)]. This had serious implications for the size of the market since such threat would induce many individuals not to take part in the market activities. Institutions had to be created to counter possibilities of ex-post opportunism, i.e., to make parties commit ex ante that they would not breach the contractual obligation ex post. ${ }^{61}$

Since impersonal exchange, characterised by the separation of quid and quo, was common feature in late medieval Europe, ${ }^{62}$ and no state had developed the legal system to enforce contracts in distant places, some system must have been put in place to mitigate the contractual problem. One such system was the community responsibility system [Greif (2003)]. Much of the trade in Europe was conducted in the context of local communities. These were self-governing units and membership of community was not easily acquired. ${ }^{63}$ Under community responsibility system (CRS), every member of the community was liable for the other member's default in inter-community exchange. The strategy for controlling opportunistic behaviour, depending upon situation, varied from property confiscation, to cessation of trade for a finite period of time (in cases of disagreement that a violation has occurred) ${ }^{64}$

Another solution to contractual problems in long distance trade involved merchant guilds. Famous among these are the German Hansa and Maghribi traders. These guilds operated on principles of multilateral reputation. German Hansa governed relationships among German merchants and foreign towns in their trading relations. Under Hanseatic League, German merchants established kontor in foreign cities that coordinated the response of German merchants in disputes with the town. It used threat of embargo as retaliation against defection. One often cited

\footnotetext{
${ }^{60}$ This is in sharp contrast to public market or 'bazaar', where quid and quo are exchanged simultaneously [Dam (2006)].

${ }^{61}$ This is in contrast to the personal exchange where repeated interaction and/or family ties are used to control chances of opportunism.

${ }^{62}$ Merchants from different parts of Europe (and indeed from other parts of the world as well) took part in the buying and selling activities in market places, along with a host of other activities like exchange of credit, future orders, etc. [Greif (2003)]. Before permanent markets were developed, regional fairs provided such opportunities for exchange. Famous example of such fairs is the Champagne fair in France [North and Thomas (1973)].

${ }^{63}$ In Venice, e.g., one had to pay taxes for twenty five years to be eligible for membership.

${ }^{64}$ In Florence, for example, thirty six cases of disputes, confiscation and cessation of trade were reported [cited in Greif (2003)].
} 
example is the Hanseatic embargo against the city of Bruges that forced the city to adhere to its contractual agreement with the German merchants ${ }^{65}$ [Greif (1994)]. Maghribi traders is yet another example of institutional innovation aimed at solving agency problem in long distance trade. It was a coalition of Jewish traders that operated in the Mediterranean zone in the eleventh century. In the absence of contractual relations, goods had to be shipped to their destination town before they could be sold. An efficient response to this situation was to use overseas agent to cut costs, instead of traveling with the goods. This posed serious agency problems as the agent could cheat in the business transactions conducted in faroff areas. The Maghribi traders got around this problem by forming a coalition that retaliated against overseas agents who acted against interest of its members. This mechanism provided a credible threat that single merchant, acting on its own in anonymous agent market, could not provide. Since Maghribi traders was a closed ethnic group, information flow was smooth and fast. Any news of agent cheating on its principal traveled quickly to other coalition members. Hence, it was in the interest of the agent to 'act honestly' and develop a clean reputation so as not to deprive himself of future business opportunities [Greif (1989)].

Successes from commercial revolution were soon translated into other institutional innovations in the seventeenth century, particularly in England. Introduction of patent laws, joint stock companies, insurance companies, creation of central bank, issuance of bank notes, discounting bills, interest on deposits are all example of innovations that created opportunities for accumulation of physical and human capital for innovative activities, for investment in productive activities and, as such, created an environment favourable for growth [North and Thomas (1973)].

\subsection{Empirical Evidence}

For a long period of time theoretical research on institutions outpaced empirical evidence. And that was the strongest criticism against this discipline. Beginning 1990s, a number of studies incorporated institutions variable in their growth regression framework. Barro (1991, 1997), Knack and Keefer (1995), Hall and Jones (1999) are some of the earliest attempts in this regard. ${ }^{66}$ They all found evidence in support of the 'institutions

\footnotetext{
${ }^{65}$ The embargo was imposed because Bruges abused rights (trading privileges) of foreign merchants. The first embargo, which was imposed in 1280, failed to constrain Bruges from these violations because at that time kontor only coordinated the German merchants present in the city. A later embargo, imposed in 1307, proved successful because by then kontor was able to coordinate response of all German traders including all potential traders from different cities.

${ }^{66}$ Although not credited for it, Kormendi and Meguire (1985) and Scully (1988) were the pioneer studies in using proxies for institutional variables (indices of economic and political freedom from Freedom House) in growth regressions. Barro (1991) also differs from other two studies in the sense that he did not use institutional quality indices but instead used war deaths and revolutions to capture political instability in growth regression framework.
} 
hypothesis'. Improving institutional quality had positive effect on economic growth. However, these earlier studies suffered from a serious estimation problem - they lacked a purely exogenous source of variation for the institutions variable. Since institutions can not be assumed to be independent of income,${ }^{67}$ their estimation procedures were bound to yield biased results. Acemogle, Johnson, and Robinson (2001) worked around this problem by utilising differences in mortality rates faced by the European colonialists as an instrument for current institutions. Their reasoning, which has been labeled as 'germs theory' of institutional development by Easterly and Levine (2003), is summarised here: Europeans adopted different colonisation strategies in different colonies. They established efficient institutions in places where conditions were suitable for their settlement (measured by low mortality rate), and extractive institutions where they could not settle in large numbers and extractive institutions were more profitable for them. Examples of settlement colonies are: USA, Canada, Australia, and New Zealand. These early institutions persisted till present time. Using differences in European mortality as a purely exogenous source of variation for institutions they then estimated the effect of institutions on incomes. Their estimates suggested that institutions explained approximately three-quarter of the income per capita differences in former colonies, and once institutions were controlled for measures of geography (distance from equator, continental dummies) did not cause income. Later, Rodrik, et al. (2002), Easterly and Levine (2003) and Kaufmann and Kraay (2002) also lend support to the institutions hypothesis

Another issue that has to be solved within this tradition is which institutions matter? North (1990) has identified two types of institutions that are needed for growth - contract enforcing institutions, and coercion constraining institutions (property rights) ${ }^{68}$ Whereas contract enforcing institutions relate to private contracts between citizens, coercion constraining institutions define contract between the state and its citizens [Acemoglu and Johnson (2003)]. In a series of papers, Djankov, Glaeser, La Porta, Lopez-de-Silanes and Shleifer (2003), Djankov, La Porta, Lopez-de-Silanes and Shleifer $(2002,2003)$ and La Porta, et al. $(1997,1998,1999)$ have stressed the importance of legal system (a proxy for contract enforcing institutions) ${ }^{69}$ for growth. Their work, more generally dubbed under "Law matters", argues that differences in legal systems

\footnotetext{
${ }^{67}$ Higher incomes can make better institutions more affordable.

${ }^{68}$ Coercion constraining institutions ensure protection of property rights against expropriation by a predatory state, whereas "the predatory state would specify a set of property rights that maximised the revenue of the group in power, regardless of its impact on the wealth of the society as a whole" [North (1981: 22)]. Also see Greif (2005) for this point.

${ }^{69}$ See Acemoglu and Johnson (2003) for this point.
} 
cause different political and economic outcomes [Glaeser and Shleifer (2002)]. Legal systems, across the world, are predominantly influenced by either English common law or French civil law traditions, ${ }^{70}$ except for a few countries which follow German, Scandinavian or socialist law. These two systems, which were transplanted to recipient countries through conquest and colonisation, are different from each other in very fundamental ways. Common law relies on independent judges, broad legal principles and oral arguments and was developed in part to protect the rights of common citizens from expropriation by the monarchs. In contrast, civil law relies on professional judges (appointed by the royalty to further the interest of the sovereign), legal codes, and written records [Glaeser and Shleifer (2002)]. As a result, both legal traditions differ in terms of degree of formalism. Djankov, La Porta, Lopez-de-Silanes, and Shleifer (2003) find that procedural formalism is much greater for civil law countries and is related with judicial delays, corruption, and unfair judicial decisions. ${ }^{71}$

La Porta, Lopez-de-Silanes, Shleifer and Vishny (1998) report that, compared to common law countries, countries governed by civil law have worse governments, i.e. more interventionist in the sense of less secure property rights, worse regulation, and inefficient implying bureaucratic delays and little tax compliance. ${ }^{72}$ Acemoglu and Johnson (2003), in an effort to "unbundle institutions" and determine which institutions matter the most, find that when measures of contract enforcement and property rights are put simultaneously in their regression model, the later trump over contract enforcement institutions. Their results imply a direct effect of property rights on long run development. Legal system (proxy for contract enforcement) does not bear a direct effect on growth, but appears to have an impact on financial intermediation (stock market development).

\section{THE ROOT CAUSE: INSTITUTIONS OR GEOGRAPHY?}

In previous sections we discussed the two schools of thought and the anecdotal evidence that they present in favour of their hypotheses. We mentioned earlier in the paper that these factors are now considered as "deeper determinants" that explain more proximate causes of growth. But which of these provides a more fundamental explanation of the divergence in economic performance across countries. The geography school argues that the climate, soil quality, water availability, and disease ecology of a region has a direct bearing on its growth potential. The institutions school, on the other hand, assigns a

${ }^{70}$ Djankov, et al. (2002a) study 'courts' and civil procedures in 109 countries. They classify 42 countries as common law countries, 40 as civil law, and rest as German, Scandinavian, or socialist tradition.

${ }^{71}$ Djankov, La Porta, Lopez-de-Silanes and Shleifer (2003) construct an index of legal procedural formalism based on the number of procedures that litigants and courts use to evict a tenant for non-payment and to collect a bounced check.

${ }^{72}$ Same is true for countries governed by social, German or Scandinavian law. In all cases, common law countries have better governments. 
primal role to the institutions of the society. For them, institutions define the incentive structure facing an individual who then decides whether to invest in capital and to engage in productive activities. The respective schools of thought have collected enough ammunition in their arsenal to win any battle over this issue. In this section, we try to swim through their arguments (and counter arguments) to get some sense of where this debate is leading us.

The geography school points out a number of important geographical correlates of modern economic growth. First, countries that lie in the tropics are poorer compared to other regions of the world. The average income of tropical countries is $\$ 3326$, of sub-tropical countries $\$ 7874$, and that of temperate countries is $\$ 9320 .^{73}$ If socialist countries are taken out of temperate zone countries then the average income of this group rises to $\$ 14828$. Twenty three of the top thirty countries - as ranked by 1995 PPPadjusted GDP per capita ${ }^{74}$-are situated in the temperate zone. The following is a map of GDP per capita in 1995 (PPP adjusted) and clearly depicts that tropical countries are poorer compared to temperate zone countries [Gallup and Sachs (1999)].

Fig. 2.

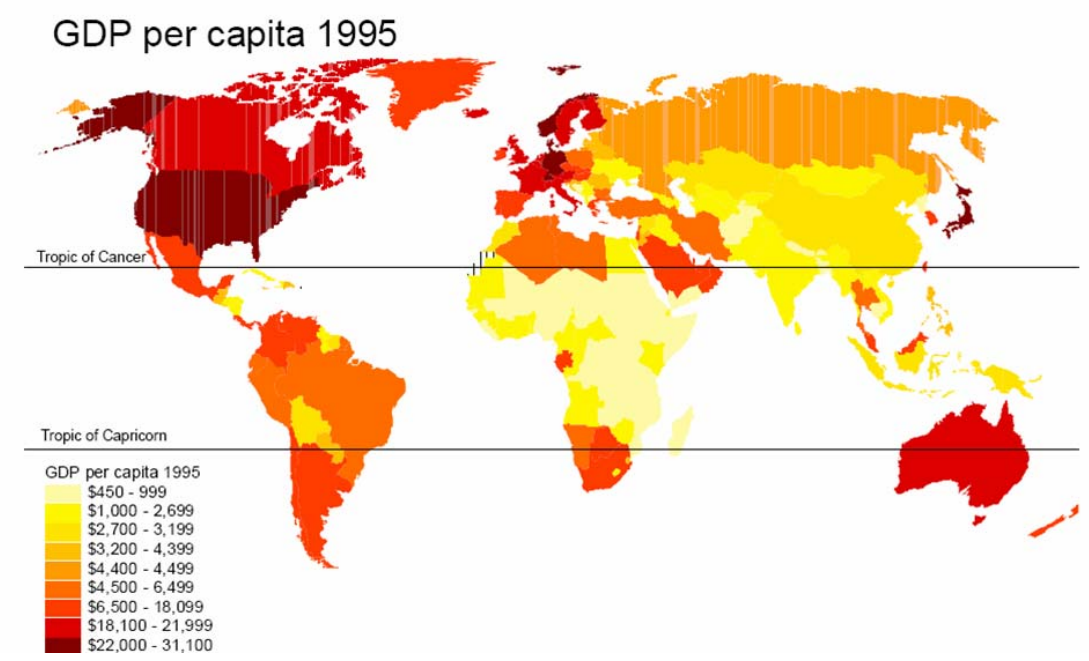

Second, coastal regions have higher incomes than landlocked regions. Except for a few countries within Western and Central Europe, landlocked economies are nearly all poor. Their average income of $\$ 1771$ is much smaller

${ }^{73}$ Tropical countries are defined as those where half or more of the land area is within the tropic of cancer and the tropic of Capricorn. Sub-tropical countries are those where half or more area is tropical or sub-tropical ecological zone, but where more than half of the area is outside the tropics.

${ }^{74}$ Their source for GDP figures is World Bank's World Development Indicators 1998. 
than the average income of non-European coastal economies (average income of \$5567) [Gallup and Sachs (1999)].

Third, economic growth has been lower for countries afflicted by high disease burden. Of the 150 countries in the world with population of over one million, 44 have intensive malaria. Of these, 35 are in Africa. Malaria intensive countries are on average poorer (average income $\$ 1526$ ) than countries without malaria (average income \$8268). The richest 31 countries have no malaria. The severity and spread of malaria is linked to the climate and ecology. ${ }^{75}$ Successful cases of malaria eradication over the past few decades belong to temperate ecological zones with low nighttime outdoor temperatures and less efficient malaria vectors. Ninety percent of world's malaria is in Africa because subSaharan Africa exclusively houses the most efficient vector ${ }^{76}$ Anopheles gambiae and where falciparum malaria predominates ${ }^{77}$ [Gallup and Sachs (2000)].

Gallup and Sachs (1999) write that "leading thinkers have pointed to four major areas in which geography will play a fundamental direct role in economic productivity: transport costs, human health, agriculture productivity (including animal husbandry); and proximity and ownership of natural resources" [Gallup and Sachs (1999:9)]. A number of empirical studies also demonstrate that geography does differentiate. Agriculture productivity in the tropics is lower than that in the temperate areas [Gallup (1998)]. Tropical countries share a higher burden of disease, which lowers their per capita incomes by almost 33 percent [Gallup and Sachs (2000)]. Landlocked countries face higher cost of transportation that lowers their growth rate [Radelet and Sachs (1998)].

In testing Diamond's theory of long-run development, Olsson and Hibbs (2000) report that countries with favourable initial biogeographic conditions made an early transition to sedentary agriculture, which gave them a head start over other regions in terms of technological advancement and thus yielded wide disparities in economic development across the world. According to their study this biogeographic endowment has a direct affect on income even today once the impact of institutions is controlled. In a later work, Hibbs and Olsson (2004) agree that institutions are strongly connected with national economic performance, and that capital accumulation and technological development, the proximate causes of growth, are "molded by the political institutions essential for the smooth functioning of markets", but draw attention to "still deeper and more-nearly-ultimate sources of contemporary prosperity"-the initial

\footnotetext{
${ }^{75}$ The geographical spread of malaria is determined by the ecology of parasites (different species of malaria plasmodia) and disease vectors (different species of Anopheles mosquitoes) [Gallup and Sachs (2000)].

${ }^{76}$ Vectorial capacity measures the efficiency with which mosquitoes carry malaria from one human to another and has major impact on the feasibility of controlling malaria (ibid).

${ }^{77} P$. falciparum is the most malignant form, compared to less serious $P$. vivax, $P$. malariae and $P$. ovale (ibid).
} 
biogeographic conditions. "At the core of long-term economic growth has been the continued development of technology... Policy makers in the years ahead should surely pay far more attention to technological change... if they are to successfully address the special problems that face the tropical world" [Sachs (2001), p. 28].

Of late, the Institutions School has come out very strongly to assert their point of view. Acemoglu et al (2005a) write, "economic institution matter for economic growth because they shape the incentives of key economic actors in society, in particular, they influence investments in physical and human capital and technology, and the organisation of production. Although cultural and geographical factors may also matter for economic performance, differences in economic institutions are the major source of cross-country differences in economic growth and prosperity" [Acemoglu, et al. (2005: 3), emphasis added]. The following is a scatter plot of GDP per capita in 1995 and a measure of property rights- "protection against expropriation risk" ${ }^{78}$ This plot shows that countries with better economic institutions (more secure property rights) have higher average incomes.

\section{Fig. 3. Average Protection against Risk of Expropriation 1985-95 and Log GDP Per Capita 1995}

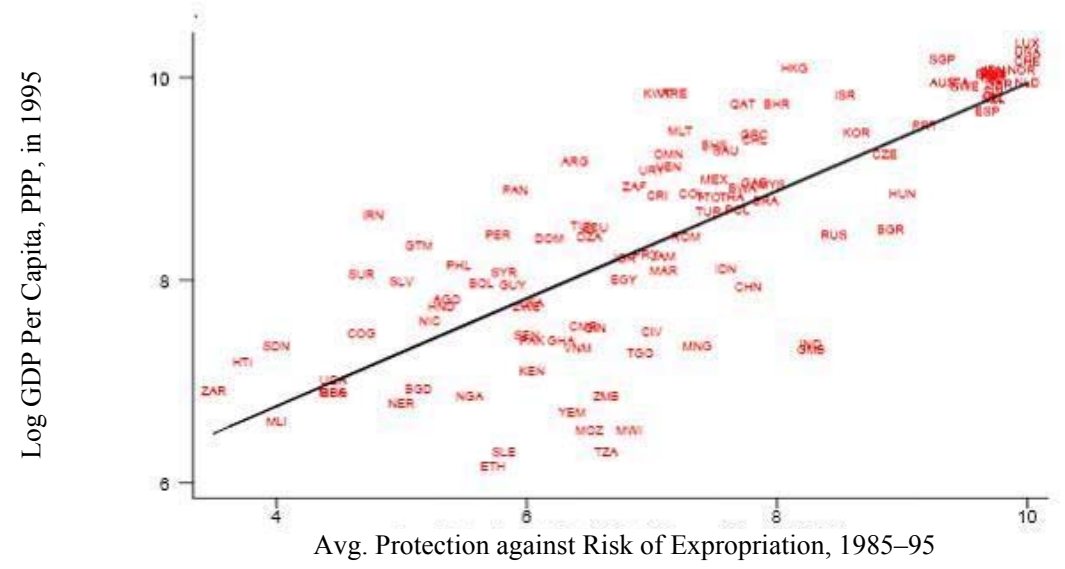

${ }^{78}$ This scatter plot and following plots are taken from Acemoglu, et al. (2005a). The GDP figures are PPP adjusted per capita GDP for 1995 from World Bank's 1999 World Development Indicators. The data on property rights comes from Political Risk services (a private company that assesses the risk of investment being expropriated in different countries), and is an average over the period 1985-1995. This measure of property right has been used extensively in research [Knack and Keefer (1995), Hall and Jones (1999), Acemoglu, et al. (2001, 2002)]. 
Does this scatter plot imply a causal relationship, i.e., do more secure property rights cause prosperity. In previous section we have quoted strong empirical evidence in favour of institutions hypothesis. In fact, Acemoglu, et al. (2001) estimate that, for former colonies, about three quarter of differences in economic performance is explained by differences in institutions. And once institutions are accounted for, geographic variables do not explain economic performance.

Empirical evidence also establishes that geography does not explain economic performance beyond its ability to explain institutional development i.e., geography does not have a direct impact on income but affects it indirectly via influencing institutions. Easterly and Levine (2003) test the "crop theory" of institutional development. The "crop theory" is due to Engerman and Sokoloff (1994) who argue that differential resource endowments of the new world influenced the type of institutions that were ultimately established. Land, soil quality and climate of Latin America and the Caribbean were suitable for large scale plantation crops (e.g., sugar). These areas developed highly stratified societies, where white minority elite dominated the majority slave labourers, with extractive institutions. Engerman and Sokoloff (1994) document evidence that the ruling elites hindered accumulation of human capital by the majority of population, and halted development of democratic institutions. North America, on the other hand, had resource endowment suitable for small family sized farms for wheat production. This led to more homogenous distribution of wealth and power in the society, so more egalitarian institutions developed that protected the rights of a broad base of citizens. Easterly and Levine (2003) test these competing hypotheses about "deeper determinants" of income and report that resource endowments affect income indirectly via institutions but do not have a direct effect on income.

Rodrik, Subramanian, and Trebbi (2002) extend this endowmentsinstitutions - income framework further by incorporating 'integration' as another "deeper determinant". They test the 'germs theory' of institutional development due to Acemoglu, Johnson, and Robinson (2001). The results of their study also confirm that 'endowments' do not explain income and hence establish the 'primacy' of institutions over geography. ${ }^{79}$

Acemoglu, et al. (2005a) further document the Korean experience in favour of the institutions hypothesis. Korea gained independence from Japan after World War II. Soon after, it was divided into North Korea and South Korea at the 38th parallel, with North Korea under the communist influence and South Korea under American influence. Before this division, Korea shared same history, culture, and geography. ${ }^{80}$ Both countries shared same disease

\footnotetext{
${ }^{79}$ Both geography and integration variables are insignificant in the regression equation.

${ }^{80} \mathrm{CIA}$ Factbook describes climate of North Korea as "temperate with rainfall concentrated in summer" and its terrain as "mostly hills and mountains separated by deep, narrow valleys; coastal plains wide in west, discontinuous in east". It describes climate of South Korea as "temperate, with rainfall heavier in summer than winter" and the terrain as "mostly hills and mountains; wide coastal plains in west and south" [Acemoglu, et al. (2005a: 18)].
} 
environment, geographical possibilities of access to markets, and transport costs.

After this split, the two parts were organised in radically different ways. Since the geography, disease environment, access to markets and transport costs did not change radically after the separation, the divergent growth experience of the two economies can only be attributed to differences in institutions. The North Korea, under Kim II Sung, opted for communist policies, and South Korea followed the path of the capitalist system. By the year 2000, per capita income in South Korea was $\$ 16100$, while that of North Korea stagnated at $\$ 1000$.

The second argument that they put forward in support of their hypothesis is "the Reversal of Fortune" among former European colonies. Around 1500, the Mughals in India, and the Aztec and Inca Empires in the Americas were among the richest of civilisations whereas the territories of North America, Australia and New Zealand were inhabited by less developed civilisations. However, after the European colonisation, there has been a reversal in incomes. Areas where the Mughal, Aztec and Inca Empires once stood are now occupied by societies that are ranked at the lower end of world income distribution, and North America, Australia and New Zealand are among the richest nations today. They argue that this reversal cannot be explained by the geography hypothesis. The only explanation is offered by the institutions hypothesis.

Fig. 4. Urbanisation in 1500 and Log GDP Per Capita in 1995, among Former European Colonies

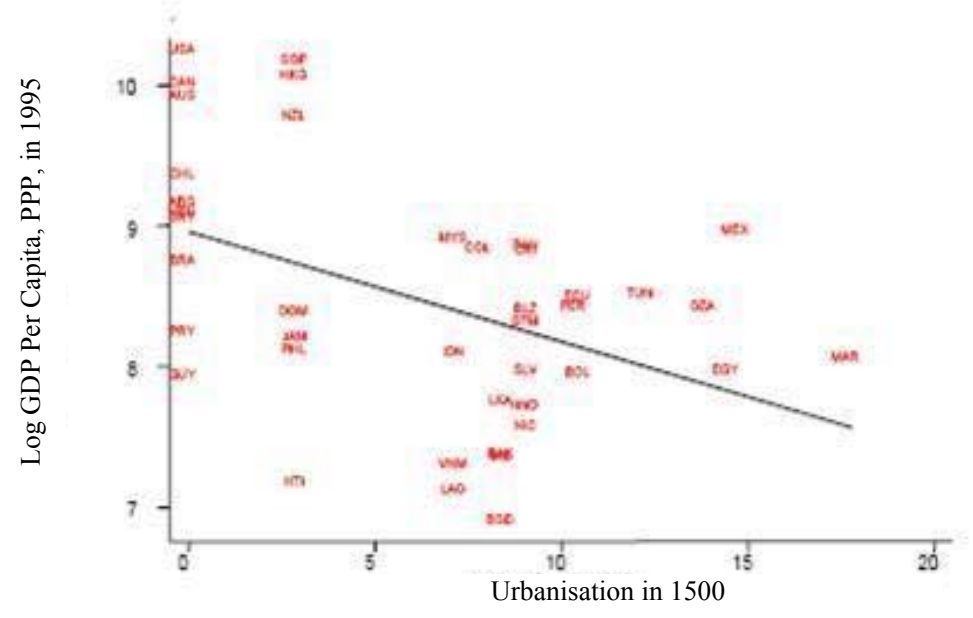


Acemoglu, et al. (2002) provide evidence that this reversal in income is explained by reversal in institutions. Using urbanisation rates in 1500 A.D. as proxy for prosperity in former colonies ${ }^{81}$ these authors show that areas that were prosperous before colonisation are poor now and vice versa. The scatter plot above (Fig. 4) shows relationship between current incomes and urbanisation in 1500. It can be seen from this plot that countries that were more urbanised in 1500 (meaning more rich) are relatively poor now.

If one goes by the geography hypothesis then areas that were rich in 1500 (owing to their geographical advantage) should be rich today since geography did not change much. This reversal is explained by the fact that European colonialist established worse institutions in places where they could not settle and instead followed an extractive policy. In contrast, areas where they could settle in large numbers (settlers colonies include North America, Australia and New Zealand), efficient institutions were put in place. Current prosperity of these settlers' colonies is explained by institutions hypothesis. The scatter plot below shows that colonies that were rich in 1500 have worse institutions today. ${ }^{82}$

Fig. 5. Urbanisation in 1500 and Average Protection against Risk of Expropriation 1985-95

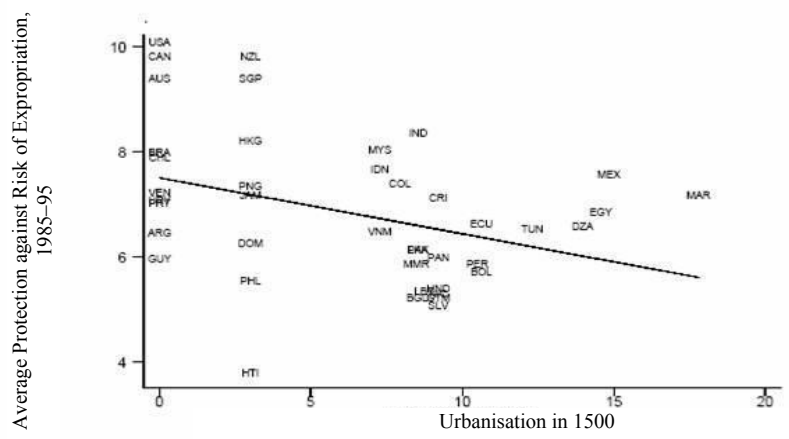

Timing of reversal is another issue for Acemoglu, et al. (2005). This reversal occurred around end of the eighteenth century when previously poor colonies took over the relatively rich colonies. This time period coincides with the beginning of the industrial revolution. Diamond (1997) had argued that

\footnotetext{
${ }^{81}$ Since reliable data for income for all colonies is not available for that period. They argue that only prosperous regions could have afforded large populations. A scatter plot of urbanisation rates and income level of present times show a positive upward slope.

${ }^{82}$ Institutional data is described above. Urbanisation rates in 1500 are proxy for prosperity at that time since income data is not available.
} 
Europe had an advantage over others continents (around 1500 when epoch of colonisation began to take place) due to its superior technology. Since this technology was ecological zone specific, i.e., suitable for temperate climates, tropical regions could not use it to their advantage. But reversal in incomes occurred around a time period that is characterised by beginning of the industrial revolution. They argue that it is hard to imagine why industrial technologies will not function in the tropics. For them, the geography hypothesis does not explain evolution of world income over the long run. Institutions are the fundamental cause of long-run growth.

\section{CONCLUSION AND POLICY IMPLICATIONS}

What is the fundamental determinant of differences in economic performance across countries? This paper highlights two such candidates: institutions and geography. The geography hypothesis asserts that these differences are accounted for by the geography (climate, geology, topography, ecology) of a region, which directly affects the quality of land, labour, and production techniques. The alternative, the institutions hypothesis, on the other

hand, documents economic development of human society as a story of evolution of the institutions of a society. According to this school of thought, it is the institutions of a society that shape the incentive structure for its people to engage in productive activities and hence achieve economic prosperity. For them, geography does not explain economic performance once the effect of institutions is accounted for. Put simply, the geography school argues for a direct impact of geography on the economic performance of countries, whereas, the institutions schools argues that the impact of geography on income runs through its effect on institutions.

In discussing the geography hypothesis, we divided this school into the classics and the contemporaries. The classical work focused attention on three aspects of geography: climate, geology and topography. The climate theories of growth assert that climate of a country shapes work habits and productivities of its people. Geology based theories emphasised role of soil fertility in shaping political and economic organisations of societies. Theories of hydraulic civilisations brought out importance of topography for development. Contemporary work in this area points out five major areas in which geography directly affects economic productivity - technological development, agriculture productivity, human health, transport costs, and proximity and ownership of natural resources.

The Institutions School, however, contends that the enormous variations in incomes across countries are due to differences in institutions. Institutions define the incentive structure for a society so that individuals decide to invest in education, equipment and machineries, innovation and attain prosperity as a result of these endeavors. They claim that the rise of the Western World can 
only be explained in terms of evolution of its institutions from inefficient to efficient ones which allowed individuals (and organisations) in search of profits to take advantage of economic opportunities.

What can be said in conclusion? Does "geography determine" or "institutions matter"? The geography hypothesis identifies important correlates of economic development, but few points are worth mentioning. The geography hypothesis, in its simplest form, stresses a kind of determinism that is timeinvariant in its effect. That is, areas that were rich initially, owing to better geographic endowments, should be rich today. However, we witness that some of the new world economies (USA, Canada, Australia and New Zealand) surpassed the initially more prosperous areas of Asia and parts of Africa. Second, geography determinism suggests an upper bound on the development capacity of the region owing to its location. It fails to explain why Singapore, despite its 'tropical location', joined the league of prosperous temperate zone economies. If geography is destiny, then why do economic fortunes of North Korea and South Korea, which share similar geography, differ so much?

Institutions matter. Existence and enforcement of property rights for a broad cross section of people; enforcement of contracts; rule of law, so that powerful elites are constrained from expropriating the property of other less powerful sections of the society; impartial and speedy dispensation of justice; honest and efficient governments are conditions that are necessary for protecting fruits of entrepreneurship without which development cannot proceed. Developing countries, like Pakistan, stand to gain a lot from investment in improving their institutional infrastructure. If Pakistan can improve the protection of private property against expropriation to the level of Singapore, its per capita income would increase manifolds nearing income levels in Singapore. ${ }^{83}$ "Recognising the importance of institutions in economic development... is the first step toward significant progress in jump-starting rapid growth in many areas of the world today" [Acemoglu (2003), p. 30].

\section{REFERENCES}

Acemoglu, D., S. Johnson, and J. A. Robinson (2001) The Colonial Origins of Comparative Development: An Empirical Investigation. American Economic Review 91: December, 1369-1401.

Acemoglu, D., S. Johnson, and J. A. Robinson (2002) Reversal of Fortune: Geography and Institutions in the Making of the Modern World Income Distribution. Quarterly Journal of Economics 117: November, 1231-1294.

\footnotetext{
${ }^{83}$ These estimates are based on results from Acemoglu, et al. (2001). Pakistan scores a 6.5 on institutional index measuring risk of expropriation against government seizure. Singapore scores 9.32 out of 10. Coefficient of institutional variable is 0.98 . Pakistan's per capita income is 7.35 (in logarithm) while that of Singapore is 10.15 . Improving its score on institutional index from 6.5 to 9.32 would raise Pakistan's income to 10.11 .
} 
Acemoglu, D. (2003) The Root Cause. Finance and Development. June, 27-30.

Acemoglu, D., S. Johnson, and J. A. Robinson (2005a) Institutions as the Fundamental Cause of Long-Run Growth. In P. Aghion and S. Durlauf (eds.) Handbook of Economic Growth. North Holland.

Acemoglu, D., S. Johnson, and J. A. Robinson (2005b) The Rise of Europe: Atlantic Trade, Institutional Change and Economic Growth. American Economic Review 95: June, 546-579.

Acemoglu, D., and S. Johnson (2005c) Unbundling Institutions. Journal of Political Economy 113: October, 949-995.

Akerlof, G. A. (1970) The Market for "Lemons": Quality Uncertainty and the Market Mechanism. The Quarterly Journal of Economics 84: August, 488500 .

Aron, J. (2000) Growth and Institutions: A Review of the Evidence. The World Bank Research Observer 15: February, 99-135.

Auty, R. M. (ed) (2004) Resource Abundance and Economic Development. WIDER Studies in Development Economics. Oxford: Oxford University Press for UNU/WIDER.

Barro, R. J. (1991) Economic Growth in a Cross-Section of Countries. Quarterly Journal of Economics 106: May, 407-443.

Barro, R. J. (1997) The Determinants of Economic Growth: A Cross-Country Empirical Study. Cambridge: MIT Press.

Barzel, Y. (1989) Economic Analysis of Property Rights. Cambridge: Cambridge University Press.

Bennedsen, M., N. Malchow-Møller, and F. Vinten (2005) Institutions and Growth-A Literature Survey. Report 2005-01. Centre for Economic and Business Research.

Bloch, H., and S. H. K. Tang (2004) Deep Determinants of Economic Growth: Institutions, Geography and Openness to Trade. Progress in Development Studies 4, 245-255.

Bulte, E. H., R. Damania, and R. T. Deacon (2005) Resource Abundance Poverty and Development.

Dam, K. (2006) Institutions, History and Economic Development. Chicago John M Olin Law and Economics. The Law School, University of Chicago. (Working Paper No. 271.)

Deacon, R. T., and B. Mueller (2004) Political Economy and Natural Resource Use. www.econ.ucsb.edu/papers/wp01-04.pdf

Demsetz, H. (1967) Towards a Theory of Property Rights. American Economic Review 57: May, 347-359.

De Silva, K. M. O. (1994) The Political Economy of Windfalls: The 'Dutch Disease'-Theory and Evidence. Downloaded from: http://pgpblog.worldbank.org/files/Dutchdisease_Migara.pdf 
Diamond, J. M. (1997) Guns, Germs and Steel: The Fate of Human Societies. New York: W. W. Norton and Company.

Diamond, J. M. http://www.edge.org/3rd_culture/diamond/diamond_p1.html.

Djankov, S., E. Glaeser, R. La Porta, F. Lopez-de-Silanes, and A. Shleifer (2003) The New Comparative Economics. Journal of Comparative Economics. (forthcoming.)

Djankov, S., R. La Porta, F. Lopez-de-Silanes, and A. Shleifer (2002) The Regulation of Entry. Quarterly Journal of Economics 117, 1-37.

Djankov, S., R. La Porta, F. Lopez-de-Silanes, and A. Shleifer (2003) Courts. Quarterly Journal of Economics 118: May, 453-517.

Easterly, W., and R. Levine (2003) Tropics, Germs, and Crops: How Endowments Influence Economic Development. Journal of Monetary Economics 50: January, 3-39.

Eggertsson, T. (1990) Economic Behaviour and Institutions. New York: Cambridge University Press.

Eifert, B, A. Gelb, and N. B. Tallroth (2002) The Political Economy of Fiscal Policy and Economic Management in Oil Exporting Countries. The World Bank, Washington, D.C. (World Bank Policy Research Working Paper 2899.)

Engerman, S. L., and K. L. Sokoloff (1994) Factor Endowments, Institutions and Differential Paths of Growth Among New World Economies: A View From Economic Historians of the United States. National Bureau of Economic Research. (NBER Historical Paper No. 66.)

Gallup, J. L. (1998) Agriculture Productivity and Geography. Harvard Institute for International Development. Downloaded from: http://www2.cid. harvard.edu/hiidpapers/agprod.pdf.

Gallup J. L., J. D. Sachs, and A. Mellinger (1999) Geography and Economic Development. Working Papers Center for International Development at Harvard University. (CID Working Paper No. 1.)

Gallup J. L., and J. D. Sachs (2000) The Economic Burden of Malaria. Working Papers Center for International Development at Harvard University. (CID Working Paper No. 52.)

GilFillan, S. C. (1920) The Coldward Course of Progress. Political Science Quarterly 35: September, 393-410.

Glaeser, E. L., and A. Shleifer (2002) Legal Origins. The Quarterly Journal of Economics November, 1193-1229.

Greif, A. (1989) Reputation and Coalitions in Medieval Trade: Evidence on the Maghribi Traders. The Journal of Economic History 49: December, 857-882.

Greif, A. (1993) Contract Enforceability and Economic Institutions in Early Trade: The Maghribi Trader's Coalition. American Economic Review 83, $525-548$. 
Greif, A., P. Milgrom, and B. R. Weingast (1994) Coordination, Commitment and Enforcement: the Case of Merchant Guild. Journal of Political Economy 102: August, 745-776.

Greif, A. (2003) Institutions and Impersonal Change: The European Experience. http://www-econ.stanford.edu/academics/greif_228_2005/Greif\%202005\% 20Impersonal \%20Exchange.pdf.

Greif, A. (2005) Commitment, Coercion and Markets: The Nature and Dynamics of Institutions Supporting Exchange. Downloaded from: http://www-econ.stanford.edu/faculty/Greif_Papers/Commitment_Coercion_ Markets.html

Gylfason, T., T. T. Herbertsson, and G. Zoega (1999) A Mixed Blessing. Macroeconomic Dynamics 3, 204-225.

Gylfason, T., and G. Zoega (2001) Natural Resources and Economic Growth: The Role of Investment. Economic Policy Research Unit (EPRU), University of Copenhagen, Department of Economics. Copenhagen, Denmark. (EPRU Working Paper Series 01-02.)

Gylfason, T. (2001a) Nature, Power and Growth. Centre for Economic Studies and ifo Institute for Economic Research. Munich, Germany. (CESifo Working Paper No. 413.)

Gylfason, T. (2001b) Natural Resources and Economic Growth: What is the Connection? Centre for Economic Studies and ifo Institute for Economic Research. Munich, Germany. (CESifo Working Paper No. 530.)

Gylfason, T. (2001c) Lessons from the Dutch Disease: Causes, Treatment, and Cures. Institute of Economic Studies. University of Iceland. Iceland. (Working Paper Series W01:06.)

Hall, R. E., and C. I. Jones (1999) Why Do Some Countries Produce So Much More Output Per Worker Than Others? Quarterly Journal of Economics 114: February, 83-116.

Harriss, J., J. Hunter, and C. M. Lewis (eds.) (1995) The New Institutional Economics and Third World Development. London: Routledge.

Hibbs, D. A., and O. Olsson (2004) Geography, Biogeography and Why Some Countries Are Rich And Others Are Poor. Proceedings of the National Academy of Sciences 101: 3715-3720.

Jütting, J. (2003) Institutions and Development: A Critical Review. OECD Development Centre. (Working Paper No. 210.)

Kaufmann, D., and A. Kraay (2002) Growth Without Governance. The World Bank. (The World Bank Policy Research Working Paper Series 2928.)

Knack, S., and P. Keefer (1995) Institutions and Economic Performance: CrossCountry Tests Using Alternative Institutional Measures. Economics and Politics 7, 207-227.

La Porta, R., F. Lopez-de-Silanes, A. Shleifer, and R. Vishny (1997) Legal Determinants of External Finance. Journal of Finance 52, 1131-1150. 
La Porta, R., F. Lopez-de-Silanes, A. Shleifer, and R. Vishny (1998) Law and Finance. Journal of Political Economy 106, 1113-1155.

La Porta, R., F. Lopez-de-Silanes, A. Shleifer, and R. Vishny (1999) The Quality of Government. Journal of Law, Economics and Organisation 15, 222-279.

Landes, D. S. (1998) The Wealth and Poverty of Nations: Why Some Are So Rich and Some So Poor. New York: W. W. Norton and Company.

Leite, C., and J. Weidmann (1999) Does Mother Nature Corrupt? Natural Resources, Corruption and Economic Growth. International Monetary Fund. (IMF Working Paper WP/99/85.)

Lucas, R. E. (1988) On the Mechanics of Economic Development. Journal of Monetary Economics 22, 3-42.

Macpherson, C. B. (ed.) (1978) Property: Mainstream and Critical Positions. Oxford: Basil Blackwell.

Maddison, A. (1995) Monitoring the World Economy 1820-1992. Development Centre Studies. OECD. Paris.

Matsen, E., and R. Torvik (2003) Optimal Dutch Disease. Norges Bank Research Department. Oslo, Norway. (Working Paper ANO 2003/3.) Downloaded from: http://www.norges-bank.no/publikasjoner/arbeidsnotater/pdf/arb-200303.pdf

Mckinley, T. (2005) Why is the Dutch Disease Always a Disease? The Macroeconomic Consequences of Scaling Up ODA. International Poverty Centre. United Nations Development Programme. (Working Paper No. 10.) www.undp-povertycentre.org/newsletters/WorkingPaper10.pdf

Montesquieu, Baron de: Spirit of the Laws. http:// plato.stanford.edu/entries /Montesquieu.

Nabli, M. K., and J. B. Nugent (1989) The New Institutional Economics and its Applicability to Development. World Development 17:9, 1333-1347.

Nakahodo, S. N., and M. S. Jank (2006) The Fallacy of the Dutch Disease in Brazil. ICONE. Institute for International Trade Negotiations. Sao Paulo, Brazil. (Working Paper March 2006.)

North, D., and R. P. Thomas (1970) An Economic Theory of the Growth of the Western World. The Economic History Review 23: April, 1-17.

North, D., and R. P. Thomas (1973) The Rise of The Western World: A New Economic History. Cambridge University Press.

North, D. C. (1978) Structure and Performance: The Task of Economic History. Journal of Economic Literature 16: September, 963-978.

North, D. C. (1981) Structure and Change in Economic History. New York: W. W, Norton and Company.

North, D. C. (1990) Institutions, Institutional Change and Economic Performance. New York: Cambridge University Press.

North, D. C. (1991) Institutions. Journal of Economic Perspectives 5:1, 97-112. 
Olsson, O., and D. A. Hibbs (2000) Biogeography and Long-Run Economic Development. Department of Economics. Göteborg University. (Working Papers in Economics No. 26.)

Olsson, O. (2003a) Conflict Diamonds. Department of Economics. Göteborg University. (Working Papers in Economics No. 86.)

Olsson, O. (2003b) Geography and Institutions: A Review of Plausible and Implausible Linkages. Department of Economics. Göteborg University. (Working Papers in Economics No. 106.)

Pejovich, S. (1990) The Economics of Property Rights: Towards a Theory of Comparative Systems. Dordrecht: Kluwer Academic Publishers.

Pritchett, L. M. Woolcock, G. Busby, and J. Isham (2004) The Varieties of Rentier Experience: How Natural Resource Export Structures Affect the Political Economy of Economic Growth. Middlebury College, Department of Economics. (Middleburry College Working Paper Series 0308.)

Przeworski, A. (2004) Geography vs. Institutions Revisited: Were Fortunes Reversed? New York University. (Working Paper Wilf Family Department of Politics.)

Radelet, S., and J. Sachs (1998) Shipping Costs, Manufactured Exports and Economic Growth. http://www2.cid.harvard.edu/hiidpapers/shipcost.pdf

Reeve, A. (1986) Property, Issues in Political Theory Series. Basingstoke: Macmillan.

Rodrik, D., A. Subramanian, and F. Trebbi (2002) Institutions Rule: The Primacy of Institutions over Geography and Integration in Economic Development. (NBER Working Paper No. 9305.)

Romer, P. M. (1986) Increasing Returns and Long-Run Growth. Journal of Political Economy 94, 1002-1037.

Ross, M. L. (1999) The Political Economy of The Resource Curse. World Politics 51: January, 297-322.

Ross, M. L. (2001) Does Oil Hinder Democracy. World Politics 53: April, 325361.

Runge, C. F. (1984) Strategic Independence in the Model of Property Rights. American Journal of Agricultural Economics 66, 807-813.

Sachs, J. D. (2001) Tropical Underdevelopment. (NBER Working Paper No. 8119.)

Sachs, J. D., and A. Warner (2001) The Curse of Natural Resource. European Economic Review 45, 827-838.

Sachs, J. D. (2003). Institutions Don't Rule: Direct Effects of Geography on Per Capita Income. (NBER Working Paper No. 9490.)

Scully, G. (1988) The Institutional Framework and Economic Development. Journal of Political Economy 96, 652-662.

Simon, H. A. (1955) A Behavioural Model of Rational Choice. Quarterly Journal of Economics 69: February, 99-118. 
Simon, H. A. (1957) Models of Man: Social and Rational. Summary available at: http://cepa.newschool.edu/het/profiles/simon.htm.

Smith, A. [1776] (1981) An Inquiry into the Nature and Causes of the Wealth of Nations (Vol 1and 2). Indianapolis, Liberty Classics.

Stehr, N., and H. v. Storch (1998) Climate Determines: An Anatomy of a Disbanded Line of Research. Downloaded from: w3g.gkss.de/staff/ storch/pdf/Climate.determines.pdf

Tietenberg, T. (1992) Environmental and Natural Resource Economics. New York: Harper Collins.

Tietenberg, T. (1994) Environmental Economics and Policy. New York: Harper Collins College.

Tisdell, C. A. (1993) Environmental Economics: Policies for Environmental Management and Sustainable Development. Aldershot: Edward Elgar.

Waldron, J. (1990) The Right to Private Property. Oxford: Clarendon Press.

Whitbeck, R. H., (1916) Review: Civilisation and Climate. The American Historical Review 21: July, 781-782.

Woods, D. (2004) Latitude or Rectitude: Geographical or Institutional Determinants of Development. Third World Quarterly 25, 1401-1414.

World Bank (2004) World Bank Atlas (36th edition). The World Bank.

World Bank (2005) World Development Indicators 2005. The World Bank. 


\section{PIDE Working Papers}

2006: 1. Remittances, Trade Liberalisation, and Poverty in Pakistan: The Role of Excluded Variables in Poverty Change Analysis by Rizwana Siddiqui and A. R. Kemal (2006). 40pp.

2006: 2. Poverty-reducing or Poverty-inducing? A CGE-based Analysis of Foreign Capital Inflows in Pakistan by Rizwana Siddiqui and A. R. Kemal (2006). 43pp.

2006: 3. Bureaucracy and Pro-poor Change by Ali Cheema and Asad Sayeed (2006). 26pp.

2006: 4. Civil Servants' Salary Structure by Faiz Bilquees (2006). 21pp.

2006: 5. Wheat Markets and Price Stabilisation in Pakistan: An Analysis of Policy Options by Paul Dorosh and Abdul Salam (2006). 17pp.

2006: 6. Stock Market Liberlalisations in the South Asian Region by Fazal Husain and Abdul Qayyum (2006). 19pp.

2006: 7. Volatitlity Spillover between the Stock Market and the Foreign Exchange Market in Pakistan by Abdul Qayyum and A. R. Kemal (2006). 15pp.

2006: 8. A Significant Shift in Causal Relations of Money, Income, and Prices in Pakistan: The Price Hikes in the Early 1970s by Fazal Husain and Abdul Rashid (2006). 18pp.

2006: 9. A Social Accounting Matrix for Pakistan, 2001-02: Methodology and Results by Paul Dorosh, Muhammad Khan Niazi, and Hina Nazli (2006). 31pp.

2006: 10. Demographic Dividend or Demographic Threat in Pakistan by Durr-e-Nayab (2006). 29pp.

2006: 11. Awake the Sleeper Within: Releasing the Energy of Stifled Domestic Commerce! by Nadeem Ul Haque (2006). 14pp. 